NBER WORKING PAPER SERIES

\title{
FROM SEPARATE AND UNEQUAL TO INTEGRATED AND EQUAL? SCHOOL DESEGREGATION AND SCHOOL FINANCE IN LOUISIANA
}

\author{
Sarah J. Reber \\ Working Paper 13192 \\ http://www.nber.org/papers/w13192 \\ NATIONAL BUREAU OF ECONOMIC RESEARCH \\ 1050 Massachusetts Avenue \\ Cambridge, MA 02138 \\ June 2007
}

I am grateful to Ken Chay, David Cutler, Claudia Goldin, Nora Gordon, Caroline Hoxby, Larry Katz, Rob Lemke, and participants in the Berkeley Center for Labor Economics seminar for helpful discussions and advice and to Margo Schlanger for help understanding the legal history. Chris Antunes, Kara Sullivan, and Garett Trombly provided excellent research assistance. All remaining errors are my own. Funding from the National Science Foundation, the American Educational Research Association, and the Spencer Foundation is gratefully acknowledged. ,The views expressed herein are those of the author(s) and do not necessarily reflect the views of the National Bureau of Economic Research.

(C) 2007 by Sarah J. Reber. All rights reserved. Short sections of text, not to exceed two paragraphs, may be quoted without explicit permission provided that full credit, including $\odot$ notice, is given to the source. 
From Separate and Unequal to Integrated and Equal? School Desegregation and School Finance in Louisiana

Sarah J. Reber

NBER Working Paper No. 13192

June 2007

JEL No. H71,H72,H75,I22

\begin{abstract}
An important goal of the desegregation of schools following the Supreme Court's decision in Brown vs. Board of Education was to improve the quality of the schools black children attended. This paper uses a new dataset to examine the effects of desegregation on public and private enrollment and the system of school finance for Louisiana. I show that the system of school finance in Louisiana had long favored whites in high black enrollment share districts. Because of this system, whites in districts with high black enrollment shares stood to lose the most from desegregation, as the gap between white student-teacher ratios and black student-teacher ratios in those districts was higher. Given the importance of districts' black enrollment share in the system of finance and the potential impact of desegregation, I examine how changes in public and private enrollment, the local property tax base, and per-pupil revenue relate to the initial black enrollment share. The analysis suggests that the Jim-Crow system of school finance -- which had prevailed for over 60 years -- unraveled as the schools desegregated. While desegregation did induce some "white flight" and reduce the local property tax base slightly, the policies had the intended effect of reducing black-white gaps in school resources, as increased funding allowed districts to "level up" average spending in integrated schools to that previously experienced only in the white schools.
\end{abstract}

Sarah J. Reber

University of California, Los Angeles

Department of Public Policy

School of Public Affairs

3250 Public Policy Building

Los Angeles, CA 90095

and NBER

sreber@ucla.edu 
In 1954, the United States Supreme Court declared separate schools for blacks and whites to be "inherently unequal" in Brown vs. Board of Education. One motivation for desegregating public schools was a concern that—despite the legal requirement that black schools be "equal" to white schools—black schoolchildren would never receive adequate resources in their schools so long as they were separate from whites, and it was hoped that educational opportunities for minority children could be improved in part by tying their fate to that of the white students in their districts. ${ }^{1}$ Fifty years later, little is known about how the desegregation effort affected resources in blacks' schools.

Previous work has shown that—despite substantial narrowing of black-white gaps in teacher salaries, student-teacher ratios and overall expenditure-black-white inequality in Southern schools remained entrenched at mid-century (Margo, 1990; Card and Krueger, 1992; Bond, 1934). The existing literature on school finance picks up in the 1970s, focusing on the school finance equalization movements of the 1970s and later. The period between the end of Margo's study (ending in 1950) and the school finance equalization studies — the period of desegregation—has gone largely unexplored. The recent $50^{\text {th }}$ anniversary of the Brown decision witnessed a plethora of retrospective books and articles about the effects of the desegregation effort in addition to widelydiscussed concerns about "resegregation." While many of these voice concerns about current racial inequality in funding, they have little to say about whether desegregation ever helped reduce inequality of funding at all. ${ }^{2}$

\footnotetext{
${ }^{1}$ Within the leadership of the National Association for the Advancement of Colored People (NAACP) and later the NAACP Legal Defense and Education Fund (LDF), there was significant debate starting in the 1930s about whether to pursue a strategy of pursuing equality for black schools under the "separate but equal" doctrine or attacking segregation itself. By 1950, the LDF pursued the latter strategy; the legal argument in Brown proposed that the stigma associated with state-sanctioned segregation harmed black children. Practical issues in enforcing separate by equal were also at play: In a 1952 discussion of what legal strategy to pursue, Spotts Robinson argued, "We had four cases...in each of the four cases... we had to go back to court because the injunctions_-equalization injunctions, mind you—were not abided by...Contempt was not the answer...To get the problem solved we must go back and this time seek further relief which involves a direct attack on segregation itself' (quoted in Greenberg, 1994). See Greenberg (1994) for an extensive discussion of the LDF legal strategy before and after Brown.

2 See, for example, Cashin (2004); Cottrol, Diamond, and Ware (2003); Ogletree (2004); Bell (2004); and Clotfelter (2004).
} 
This paper is the first of which I am aware to study the effects of desegregation on school finance in addition to other outcomes. I examine the effects of desegregation policies on a number of outcomes, including measures of segregation, white flight to public and private schools, the local property tax base, per-pupil funding from different sources, and student-teacher ratios by race. I show that desegregation policy was quite effective in reducing racial segregation across schools within school districts in the late 1960s. These changes induced significant shifts in white enrollment, both to private schools and from public school districts with higher black enrollment shares to those with lower black enrollment shares. Despite these white enrollment responses, however, blacks' exposure to whites and whites' exposure to blacks in schools rose substantially.

Next, I show that the Jim-Crow era system of school finance continued to operate well into the 1960s, but unraveled rapidly during the period of desegregation. Historically, Southern state governments (including Louisiana's) distributed aid to local school districts roughly on a per-pupil basis, irrespective of race. However, within school districts, revenue was directed disproportionately to the white schools. ${ }^{3}$ In districts with large numbers of black students relative to white students (high black enrollment share districts), the white schools could achieve high per-student spending by skimming revenue from black schools. Gaps between the funding of black and white schools were therefore larger in districts with high black enrollment shares. ${ }^{4}$ Without changes in the system of school finance, funding in integrated schools would be a weighted average of spending in the formerly white and black schools; therefore, whites in districts with high black enrollment shares would have seen funding for their schools fall more upon desegregation—relative to whites in "whiter" districts. But in fact, whites in those districts did not see resources in their schools fall more. Instead, total average revenue increased, and the additional revenue was disproportionately directed to high black enrollment share districts so that spending could be "leveled up" to the spending level of the formerly white schools. In addition, enrollment declined in higher black enrollment share

\footnotetext{
${ }^{3}$ I discuss the historical origins of this system of finance further below.

${ }^{4}$ Patterns of spending across states and counties in the South with different black enrollment shares and the mechanisms described here were first discussed by Bond (1934) and later by Margo (1990). I discuss this in greater detail in Section II.
} 
districts, propping up per-pupil revenue. The results suggest that desegregation was successful in increasing the resources devoted to schools attended by blacks and reducing black-white inequality of school resources. ${ }^{5}$

The paper proceeds as follows: Section II provides background on school desegregation and school finance and a review of the previous literature. Section III describes the data used in the analysis. Section IV discusses the empirical strategy. The results are reported in Section V, and Section VI concludes.

\section{Background}

School Segregation, School Finance, and the Courts

The Supreme Court declared separate schools for black and white children to be "inherently unequal" in 1954, but few Southern school districts made meaningful progress toward integration in the first decade following Brown. The trends in segregation discussed below for Louisiana (Figure 1) are typical of states of the former Confederacy. Before 1965, there was virtually no desegregation activity as districts resisted desegregation. ${ }^{6}$ Following the passage of the 1964 Civil Rights Actwhich prohibited any entity that discriminated on the basis of race from receiving Federal fundingand the Elementary and Secondary Education Act of 1965-which dramatically increased potential Federal funding for schools—districts in the South took their first steps towards integration. Following a series of Supreme Court decisions between 1968 and 1971, large-scale court-ordered desegregation plans were implemented in Louisiana and throughout the South, reducing segregation substantially. ${ }^{7}$

Although equalizing resources available to black and white children was one goal of integration, at least implicitly, the courts had little to say about school finance in relation to school

\footnotetext{
${ }^{5}$ In other work (Reber, 2006), I show that these increases in per-pupil revenue during the period of desegregation appear to have produced increases in blacks' educational attainment. Previous work has also found beneficial effects of court-ordered desegregation plans on black high school dropout rates (Guryan, 2004).

${ }^{6}$ Also see Welch and Light (1987) for more details on the legal history of school desegregation.

${ }^{7}$ See Reber (2005) for an analysis of the effects of the implementation of court-ordered desegregation plans on segregation.
} 
desegregation until later in the 1970s. In the analysis of desegregation and school finance in Louisiana, I will focus on the period 1960-1975, before states were required to provide additional funding explicitly as part of desegregation plans; and no such funding was distributed to districts in Louisiana. Observed changes in revenue did not arise specifically as part of a desegregation plan during the period studied here.

Southern School Finance before Brown: Previous Literature

How desegregation is likely to affect school funding and school quality for blacks depends on the system of school finance before desegregation. While local finance of primary and secondary education, especially through local property taxes, was important nationally during this period, in Louisiana, as in many Southern states, the state government was a relatively important source of revenue for school districts, with the average district raising only about 20 percent of its revenue locally. So concerns about negative effects of desegregation on school district finances through the local property tax base are less prominent than they might be elsewhere, and considering the role of state revenue is important. ${ }^{8}$

Writing in 1934, Horace Mann Bond showed there were large differences in average spending per pupil for blacks and whites across the South, but the average gaps masked wide variation across counties. Bond pointed to the role of a district's racial composition in the Southern system of school finance to explain this variation: "In any other section of America, we should refer our discussion of the per capita payments to the wealth of assessed valuation of the county involved. In the South it is evident that the factor of greatest significance is the number of Negroes in the population.” Bond and later Margo-in his 1990 book Race and Schooling in the South, 1880-1950_ showed how the ratio of spending on white schools to that for blacks was strongly positively related to a county's black share of enrollment.

\footnotetext{
${ }^{8}$ In a study of the effects of the implementation of a desegregation plan in Atlanta on property values, Clotfelter (1975) found that house prices fell more in districts where the black share of enrollment in the local school rose more between 1960 and 1970.
} 
Margo and Bond propose that in the late 19th century, the combination of black

disenfranchisement and growing demand for quality in white schools eroded the black-white ratio of school spending. Following Reconstruction, funding for schools in the South was segregated by race, with taxes from blacks funding the black schools and taxes from whites funding the white schools. ${ }^{9}$ This segregation of funding (but not of students) was disallowed by the courts over time. These decisions, together with the Supreme Court's "separate but equal" ruling, made it difficult for state governments to discriminate in the allocation of funding to counties and local school districts. ${ }^{10}$ Thus, in the first half of the $20^{\text {th }}$ century, Southern state governments allocated revenue to counties on a per-pupil basis, without regard to race. However, within districts, payments allocated to black pupils could be, and indeed were, directed disproportionately to the white schools. This meant that whites in districts with many blacks could finance better schools without raising additional revenue locally; Bond referred to this as the "cash value of a Negro."11

During the 50 years leading up to Brown, these black-white gaps did narrow substantially, from quite high levels (Margo, 1990; Card and Krueger, 1992). For example, Margo estimates that the average ratio of black to white per-pupil expenditure on teacher salaries for 13 Southern states rose from 0.43 in 1910 to 0.74 in 1950. Even so, I show that the system described by Bond and Margo still operated in the first half of the 1960s in Louisiana, before large-scale desegregation. Despite the "separate but equal" requirement of Plessy vs. Ferguson, for the 1959-60 school year, the average district in Louisiana spent 72 cents per pupil on instruction in the black schools for every dollar spent

\footnotetext{
${ }^{9}$ Also see Kousser (1991) for a discussion of the history of school segregation and finance in Louisiana before 1900.

${ }^{10}$ See Kousser (1980) for a discussion of the Court's ruling against separate funding for black and white schools in Kentucky. The response parallels the response to desegregation in Louisiana 80 years later. When funds could no longer be segregated by race, Kentucky voters chose to increase spending for black schools rather than decrease spending for white schools, approving an increase in statewide taxes that tripled state-level expenditures for blacks (Kousser, 1980).

${ }^{11}$ It is interesting to note that this system produced substantial between-district inequality of resources among white students, with whites in high black enrollment share districts having substantially more funding for their schools. There is a political economy explanation for why this system persisted for so long: although blacks in Louisiana generally were not permitted to vote during this period, legislators were allocated on the basis of total population. This meant that whites in areas with large black populations effectively had more votes in the legislature than their counterparts in whiter areas.
} 
in the white schools, ${ }^{12}$ and the student-teacher ratio for blacks remained above that of whites

through at least 1965 . These average gaps mask substantial variation across districts; I show below that high black enrollment share districts had substantially higher black-white gaps in student-teacher ratios. I examine how this system changed when desegregation eliminated whites' ability to divert state funding for black children to their own schools.

\section{Data}

I use a new dataset, compiled from the Annual Financial and Statistical Reports of the Louisiana Department of Education and the Biennial Reports of the Louisiana Tax Commission for 1955-1975.13 Annual school-district-level data on enrollment, revenue by source (local, state, and Federal ${ }^{14}$ ), enrollment by race, and classroom teachers by race, education, and experience for Louisiana's 64 Parish and 2 City districts ${ }^{15}$ were obtained from Louisiana Department of Education Annual Financial and Statistical Reports for 1955-1975. ${ }^{16}$ (All years refer to the fall of the school year.) Data for the two City districts was combined with that of their respective Parishes (counties) and matched to data on total assessed valuation (the local property tax base), as well as the value of real property and non-real property from Biennial Reports of the Louisiana Tax Commission for 1955-1975. ${ }^{17}$ I link these new datasets with demographic data-including population, the fraction of the population living in urban areas, and measures of income and poverty for each Parish from the 1960 and 1970 Censuses.

\footnotetext{
12 The Annual Financial and Statistical Report published spending for instruction separately for blacks and whites through 1959. According to Margo (1990), this ratio was less than 0.2 around 1910.

13 National datasets on school district finances for this period are scarce. The Census of Governments surveyed school districts every five years during this period. Only information for the larger school districts was published, information on numbers of students and teachers by race was not available, and the five-year intervals between surveys would make it difficult to pin down the timing of school finance changes. 14 Total Federal revenue is not consistently reported separately from state revenue for the whole period. Federal money collected for Elementary and Secondary Education Act programs can be identified starting in 1965 (the first year money was distributed under that program). I therefore divide non-local revenue into Federal ESEA, State Public School Fund (MFP, state equalization aid), and other non-local revenue, which are reported consistently over time.

${ }^{15}$ Before 1967, there were 3 City districts; Lake Charles City consolidated with its Parish.

${ }^{16} \mathrm{~A}$ few years are missing or incomplete, but the largest gap is a single year. Missing data generally resulted from difficulty in acquiring the relevant report for that year.

17 The City districts cannot be considered separately because the Tax Commission reports assessed valuation at the Parish level. Excluding these from the analysis does not affect any of the results.
} 
In order to measure how racially segregated a district's schools are, data on the racial composition of students at the school level are required; but the Annual Financial and Statistical Reports report enrollment by race at the district level only. Between 1967 and 1976, the Department of Health, Education, and Welfare (HEW) Office of Civil Rights (OCR) collected such information for a sample ${ }^{18}$ of school districts. I use HEW's calculation of several commonly used measures of segregation constructed from the school-level data ${ }^{19}$; these measures are described more below. In order to extend the series earlier than 1967, I use data on the number of black students in school with any whites collected by the Southern Education Reporting Service (SERS, various years) to estimate the average dissimilarity index and exposure of blacks to whites for the early 1960s. ${ }^{20}$

\section{Empirical Strategy}

To examine the effects of desegregation in Louisiana on public and private enrollment, the local property tax base (assessed valuation), revenue by source, and student-teacher ratios, I exploit variation in how much whites in different districts are expected to be affected by desegregation. Statewide, segregation fell rapidly between 1965 and 1970, and reductions were particularly sharp between 1968 and 1970. Not all whites were equally affected by the dramatic state-wide declines in segregation; in particular, the effect depended on the share of the districts' enrollment that was black.

Whites in districts with high black enrollment shares would be affected more by desegregation for two reasons: First, whites' exposure to blacks would increase more in high black enrollment share districts after desegregation ${ }^{21}$; second, due to the important role of initial black

\footnotetext{
18 The size of the sample varied by year; in general, sample sizes were smaller in odd years. The sample selection criteria favored larger schools districts and those with substantial minority enrollment.

19 The 1967 survey was only published in print. These data were entered and the segregation indexes calculated by the author.

${ }^{20}$ SERS reports the share of black students in school with any whites. When only a small share of blacks were in school with whites, the dissimilarity index can be approximated by 1 - (share of blacks with any whites) and exposure of blacks to whites is approximately equal to the share of blacks with any whites (since those in school with whites were in schools that were virtually 100 percent white and the remaining blacks were in schools that were virtually 100 percent black).

${ }^{21}$ Exposure of whites to blacks in a district will depend on two factors: the black share of enrollment and how evenly blacks and whites are distributed across schools within the district. One might have expected that it would be easier (politically and logistically) to spread blacks evenly across schools in districts with lower black enrollment shares. If this were the case, whites in high black enrollment share districts might not see larger increases in exposure to blacks as a result of desegregation. The dissimilarity index provides a measure of how
} 
enrollment share in the pre-desegregation system of school finance, gaps between white school funding and black school funding were larger in high black enrollment share districts. I therefore examine how changes in the outcomes of interest during the time of desegregation varied by initial black enrollment share. The remainder of this section documents trends in segregation and the preexisting system of school finance in more detail before presenting the estimating equations.

\section{Trends in Segregation in Louisiana}

As was common in the South, Louisiana state law required school districts to maintain separate schools for black and white children from shortly after the Civil War until after Brown. Substantial resistance prevented meaningful integration of Louisiana schools for more than ten years following Brown. New Orleans was the first to desegregate, under court order: in the early 1960s, a handful of black students were enrolled in white schools, and starting in the mid-1960s, the district implemented a more substantial district-wide desegregation plan. Most other districts followed, often under court order, in the late 1960s and early 1970s.22

I present trends in several commonly used measures of school segregation. The dissimilarity index is calculated for two mutually-exclusive groups, in this case blacks and whites. This index provides a measure of how closely the racial composition of schools in the district match the racial composition of the district as a whole. ${ }^{23} \mathrm{~A}$ dissimilarity index of 1 means that the schools are perfectly segregated by race; an index of 0 indicates that the schools are integrated, that is, every

evenly blacks and whites are distributed across schools, given the black enrollment share (it can be interpreted as the share of black students who would have to switch to another school to achieve a racial balance in every school that is the same as the racial balance of the district). While there is variation in the change in the dissimilarity index across districts, it is uncorrelated with initial black enrollment share. High black enrollment share districts do not appear to have more or less intensive desegregation plans.

22 See Reber (2005) and Welch and Light (1987) for more details on the history of desegregation nationally.

23 The dissimilarity index is calculated as follows:

DISSIMILARITY $=\frac{\sum_{s} \text { Total }_{s} \times \mid \% \text { Black }_{s}-\% \text { Black } \mid}{2 \times \text { Total } \times \% \text { Black } \times(1-\% \text { Black })}$,

where Totals is the total enrollment in school $s, \%$ Black $k_{s}$ is the black share of enrollment in school $s$, Total is the total enrollment in the district, and \%Black is the black share of district enrollment. The index ranges from 0 to 1 and can be interpreted as the fraction of black students who would have to be reassigned to another school to achieve racial balance in every school. The index is symmetric with respect to the two groups, so it can also be interpreted as the number of whites who would need to be reassigned to achieve racial balance in every school. 
school in the district has the same racial composition as the whole district. The exposure of blacks to whites is the white share of enrollment in the average black's school and also ranges from 0 to 1; similarly, the exposure index for whites to blacks is the black share of enrollment in the average white's school. ${ }^{24}$

Figure 1 shows trends in segregation for Louisiana: Through 1966, reductions in segregation were minimal—only 3.4 percent of blacks were in school with any whites more than a decade after Brown. Between 1966 and 1968, there was a small but noticeable reduction in segregation. Some have argued that the 1964 Civil Rights Act (CRA)—which prohibited any entity that discriminates on the basis of race from receiving Federal fundstogether with the 1965 Elementary and Secondary Education Act (ESEA)—which substantially increased Federal aid to elementary and secondary education—gave resistant Southern school districts an incentive to desegregate. ${ }^{25}$ The combination of the CRA, ESEA, and stepped-up Federal oversight prompted most districts to move away from complete segregation by 1968. The exposure index indicates that in 1968, the average black student was in a school that was about 10 percent white, while the average district was 61 percent white.

Between 1968 and 1970, all measures registered substantial reductions in school segregation as districts across the state implemented more substantial plans following the Supreme Court's

\footnotetext{
${ }^{24}$ The exposure index for blacks to whites is the weighted average of the white share of enrollment in schools, weighted by black enrollment: BLACK EXPOSURE $=\sum_{s} \%$ White $_{s} \times \frac{\text { Black }_{s}}{\text { Black }}$, where \%Wbite is white share of enrollment in school $s$, Black is black enrollment in school $s$, Black is total black enrollment in the district. The exposure index for whites to blacks is calculated similarly:

WHITE EXPOSURE $=\sum_{s} \%$ Black $_{s} \times \frac{\text { White }_{s}}{\text { White }}$.

25 See, for example, Boozer, Krueger, and Wolkon (1992) and Orfield (1975).
} 
decision in Green. ${ }^{26}$ The dissimilarity index fell from an average of 0.90 in 1968 to 0.43 in 1970; these reductions were maintained at least through $1976 .{ }^{27}$ Black exposure to whites rose by an average of 32 percentage points to nearly 43 percent between 1968 and 1970.

The Importance of Black Enrollment Share: White Exposure to Blacks

The initial black share of enrollment in the district was a very strong predictor of whites' exposure to blacks after desegregation. This is not surprising, since whites cannot be in school with many blacks if they are not in a district with many blacks. Figure 2 shows the relationship between districts' black share of enrollment in 1961 and the exposure of whites to blacks in 1970 (exposure of whites to blacks was essentially 0 in 1965 , so this can also be interpreted as the change in whites' exposure to blacks between 1965 and 1970).

If all districts integrated fully and their black share of enrollment did not change between 1961 and 1970, the points would lie on the 45-degree line. Most are below the 45-degree line suggesting integration was incomplete, but the black share of enrollment before desegregation is a very strong predictor of whites' subsequent exposure to blacks. ${ }^{28}$

The Importance of Black. Enrollment Share: Revenue and Race before Desegregation

As discussed in Section II, in segregated Southern districts, whites directed some of the state revenue allocated for black students to white schools, so that whites in blacker districts would be able to support the same school quality while raising less revenue locally, compared to their counterparts in predominately white districts. Indeed, the evidence suggests that this was the case in the early 1960s in Louisiana. ${ }^{29}$

${ }^{26}$ In Green vs. New Kent County (1968, 391 U.S. 430), the Supreme Court found that "freedom of choice" plans did not produce sufficient desegregation. Following this decision, more desegregation plans with mandatory reassignments, sometimes facilitated by busing, began to be required by the courts.

27 This is the latest year for which segregation data are available before the Common Core of Data began collecting enrollment by race at the school level in the mid-1980s.

${ }^{28}$ I use the black share of enrollment from 1961, early enough that it plausibly would not have been affected by desegregation policies or their anticipation. In fact, the black share of enrollment is fairly stable over time, and the graph would look similar for the 1965 black share of enrollment. Whites' exposure to blacks cannot be greater than the white share of enrollment in the district. A few points lie above the 45-degree line-the black share of enrollment increased in these districts between 1961 and 1970.

${ }^{29}$ Cameron Parish is a clear outlier in revenue from local sources and is excluded from the analysis. In 1962, for example, the district raised $\$ 425$ per pupil from “Rent, Leases, Royalties, etc. from School Lands." The next- 
Figure 3 shows the relationship between the black share of enrollment and per-pupil revenue from local sources (primarily local property taxes), the state Minimum Foundation Program (allocated by the equalization formula), other non-local sources (including federal revenue and nonformula-based state aid) and all sources for 1961.30 The top two panels show that whiter districts raised more revenue locally, but received slightly less (but statistically insignificant) aid from the state MFP; revenue from other non-local sources was unrelated to the black enrollment share. Overall, whiter districts raised more revenue per pupil; in a bivariate regression of total per-pupil revenue on black share of enrollment, the coefficient is $-\$ 479$ (2003 CPS-adjusted dollars) ( $\mathrm{p}$-value $=0.04)$.

Even though districts with high black enrollment shares brought in less revenue, Figure 4 shows that whites in those districts enjoyed relatively small class sizes. ${ }^{31}$ Teachers in Louisiana remained completely segregated by race through 1965 (SERS, 1966), so the student-teacher ratio for black schools and white schools can be calculated from the district-level data on teachers and enrollment by race. A district's black student-teacher ratio is the number of black students divided by the number of black teachers; the white student-teacher ratio is calculated similarly. Figure 4 shows the relationship of students per classroom teacher to the black share of enrollment in 1961. The slope of the regression line for whites (top panel) is -6.7 ( $\mathrm{p}$-value $<.001$ ), while the slope for blacks (bottom panel) is a statistically insignificant 0.12 . These relationships held until the mid-1960s when schools began to desegregate.

The evidence suggests that segregation of schools allowed districts to provide better resources in white schools compared to black schools, despite Plessy; and whites in districts with

highest district raised $\$ 88$ per pupil from such sources, and the average for all districts excluding Cameron was $\$ 3.10$ per pupil. In the 1930s, oil was discovered on the district's Sixteenth Section lands (lands set aside at the time of statehood to provide income for schools), providing substantial income for the district (personal communication, Margaret Jones, Business Manager, Cameron Parish School Board). In some years, the Parish had so much revenue from its land that it did not receive any income from the state Minimum Foundation Program. Cameron Parish also had a very low black share of enrollment so can affect the estimated relationship between black enrollment share and the finance variables.

30 The scatter-plots look similar for other years between 1961 and 1965.

31 Through 1959, the Annual Financial and Statistical Report includes separate tables for instructional spending in black and white schools. The average black-white ratio for 1955, 1957, and 1959 was 0.72 ; for years when both were reported, the black-white expenditure ratio and the black-white ratio of class size (student-teacher ratio) were highly correlated, with a correlation coefficient of -0.87 . 
many blacks could have higher-quality schools without raising significant local revenue. ${ }^{32}$ As white and black schools combined, whites would therefore expect to see considerable declines in the resources available in the schools they attended if desegregation proceeded without increasing the average resources in the district. This decline would be particularly severe in districts with high black enrollment shares, where the difference between the white student-teacher ratio and the average student-teacher ratio was largest. ${ }^{33}$

Estimating Equations

To examine how enrollment, local property tax base, and revenue responses to desegregation varied by initial black enrollment share, I first estimate the simple correlation of changes in the dependent variables of interest around the time of desegregation (1965-1970) with the 1961 black share of enrollment — early enough so that it was plausibly unaffected by desegregation:

$$
\text { (1) } \Delta y_{i}=\alpha+\beta \text { PercentBlack61 }+\varepsilon_{i} \text {. }
$$

For some outcomes, I also estimate year-by-year bivariate regressions of the outcome on initial black enrollment shares in order to more clearly identify turning points in the relationship. Of course, districts with high black enrollment shares may have differed from whiter districts on a number of characteristics that could have been related to the dependent variables. Most notably, black Louisianans had significantly higher-than-average poverty rates: in 1960, 72.9 percent of black Louisianans lived in poverty, compared to 26.3 percent of non-blacks; only 36.2 percent of blacks had complete indoor plumbing, compared to 85.7 percent of whites. ${ }^{34}$ These differences do not

\footnotetext{
${ }^{32}$ I only measure one aspect of school quality — student-teacher ratios; it is likely that gaps in other, less easily measured aspects of quality were even larger. After all, black-white quality gaps were illegal, but even on measured (and published) attributes, the black and white schools differed. On the other hand, the Coleman Report suggested that by 1965, black and white facilities were surprisingly equal in the South, in part because many new black schools had been opened in the years leading up to Brown (perhaps in an attempt to deter integrationist efforts) and were therefore newer.

${ }^{33}$ For example, in 1961, the gap between the student-teacher ratio for whites and the district average student-teacher ratio (for blacks and whites together) averaged 0.74 for the districts in the lowest quartile of black enrollment share (averaging 19 percent black), compared to 4.2 for the highest quartile (averaging 62 percent black).

${ }^{34}$ Because the Federal Poverty Line (FPL) had not been established at the time of the 1960 Census, tabulations of poverty rates at the Parish (county) level are not available. Poverty status was calculated after the fact for the 1960 IPUMS, but the most-detailed geographic identifier in that dataset is the state.
} 
simply reflect differences in the rate at which the two groups live in rural areas, as the fraction of blacks and nonblacks who lived in rural areas were similar. These large racial poverty gaps persisted in 1970. Not surprisingly, the correlation between the black enrollment share and measures of economic disadvantage at the Parish level is also high (Table 1). I therefore include measures of economic disadvantage from the 1960 Census in some specifications:

$$
\text { (2) } \Delta y_{i}=\alpha+\beta \text { PercentBlack61 }_{i}+X_{i} \gamma+\varepsilon_{i}
$$

where $X$ is a vector of Parish characteristics, including per-capita income (1959), the percent of households with complete plumbing (1960), percent of households with income below $\$ 3,000$ (1959), the (log of ) total population (1960), and the percent of the population living in urban areas (1960).

\section{Results: Responses to Desegregation}

\section{"White Flight": Public and Private Enrollment Responses—Statewide Trends}

Statewide, desegregation was associated with a noticeable shift of enrollment from public to private schools that can be seen even in the aggregate trends for the state (Figure 5). Enrollment of whites in public schools, which had been steadily rising, dropped by nearly 30,000 students as schools desegregated between 1968 and 1970. Conversely, the downward trend in white private school enrollment was reversed, rising by 26,500 students over the same period—a 25 percent increase..$^{35}$ These students appear not to have returned to the public system, as white private school enrollment remained elevated throughout the 1970s.

\section{Public and Private Enrollment Responses_Differential Change by Initial Black Enrollment Share}

If the statewide decline in public and increase in private enrollment between 1968 and 1970 was in fact due to desegregation, we would expect white flight to be more pronounced and private school enrollment to rise more in districts where whites were more exposed to blacks after desegregation—-those with high initial black enrollment shares. Indeed, Table 2 shows that this was

35 Private schools that do not want state accreditation are not required to report their enrollments and are not included in these figures. The level of private school enrollment is therefore underestimated, and the increase from 1968-1970 may be underestimated to the extent that new, unaccredited schools were opened in response to desegregation. 
the case. Table 2 reports results of estimating equations (1) and (2) with the change between 1965 and 1970 in the natural log of white public enrollment, the natural log of total white enrollment (public and private enrollment), and the percent of white students in private schools. The results for the log change in white public enrollment are reported in columns (1)-(3). In the first specification with no controls, the coefficient on black enrollment share is -1.1 , indicating that a 10 percentage point increase in 1961 black enrollment share was associated with an additional reduction in white public school enrollment of $11 \log$ points between 1965 and 1970. Controlling for other pre-existing characteristics of Parishes-including the change in the log of white enrollment from 1961 to 1964 (column (2)) — has little effect on the estimated coefficient on 1961 black enrollment share. Finally, to control for other factors that might have affected the number of children in a Parish, the third specification also includes a control for the change in (the natural log of) lagged births in the Parish (column (3)). The lagged births variable is the sum of white births for all the cohorts who would be in $1^{\text {st }}$ through $12^{\text {th }}$ grades during the school year; the inclusion of this variable also does not affect the estimated coefficient on black enrollment share. ${ }^{36}$

No district in Louisiana remained completely segregated by race by 1970 , so changes in segregation across districts did not vary on the extensive margin. The change on the intensive margin was highly correlated with the initial black enrollment share. The fact that white enrollment declined more in high black enrollment share districts suggests that whites cared not only whether there were any blacks in their schools (the extensive margin), but also how many blacks were in their schools (the intensive margin).

There are two possible sources of the relative decline in white enrollment in high black enrollment share districts—-whites could have shifted to private schools in the same district at a higher rate in blacker districts or moved to districts with lower black enrollment shares. If all the response was on the private school margin, the coefficient on initial black enrollment share would be zero with change in total (private plus public) white enrollment as the dependent variable. Results for

${ }^{36}$ For example, lagged births for 1965 is the sum of births in the years 1948 through 1959. 
the change in the log of total white enrollment are reported in columns (4)-(6) of Table 2. The coefficient is negative and significant in all three specifications, suggesting that not all of the "white flight" was to private schools. The coefficient of -0.52 on black share of enrollment compared to 1.1 for the change in public enrollment suggests that differential increases in private school enrollment accounted for about half of the differential decline in public school enrollment in districts with high black enrollment shares.

In columns (7) and (8), I estimate equations (1) and (2) for the change in the share of white students enrolled in private schools. Not surprisingly, this measure of private school enrollment also rose more in blacker districts; a 10 percentage point increase in black enrollment share is associated with an additional 4.5 percentage point increase in the fraction of students in private schools. The raw data indicate that ten percent of districts had increases in the share of whites in private school of more than 33 percentage points, so white flight to private schools was quite substantial in some districts. Again, the coefficient on initial black enrollment share is statistically significant and consistent across specifications. ${ }^{37}$

These results suggest that there was white flight out of districts with high black enrollment shares both to alternative public school districts with fewer blacks and to private schools. On the one hand, this raises concerns about the potential for declining property values and support for public schools; on the other hand, enrollment declines mean that districts had fewer students to support. To show how the total size of the student population that districts had to support changes in high and low black enrollment share districts, columns (9) and (10) of Table 2 shows results with the (log) change in the total (black and white) public enrollment as the dependent variable. The coefficient on initial black enrollment share is -0.67 (this is also not sensitive to what controls are included), confirming that the total number of students supported in the public schools did decline more in high black enrollment share districts.

${ }^{37}$ I also experimented with including the square of the initial black enrollment share in the regressions reported in Table 2 to assess whether the response was non-linear in black enrollment share; this variable was generally insignificant, so I do not report the results here. 
Local Property Tax Base Responses

The substantial white flight from high black enrollment share districts raises concerns about declining property tax bases in those districts. In fact, total assessed valuation did fall more between 1965 and 1970 in districts with higher initial black enrollment shares, although the decline is not statistically significant and the estimated coefficient varies somewhat across specification (Table 3, columns (1)-(3)). The pattern of coefficients is similar for real assessed valuation (real estate) and non-real assessed valuation considered separately. ${ }^{38}$ Although the point estimates indicate that the property tax base fell more in high black enrollment share districts, public enrollment also fell more in these districts (Table 2, column (9)), so assessed valuation per pupil actually increased more in districts with high black enrollment shares (Table 3, columns (8) and (9)). Concerns about desegregation harming local districts' funding capacity seem not to have been borne out in Louisiana. Revenue Responses: Per-Pupil Revenue by Source—Statewide Trends

Figure 6 shows trends in average per-pupil revenue from different sources: local (primarily property and sales taxes), the state Public School Fund (distributed according to the Minimum Foundation Program (MFP) formula ${ }^{39}$ ), Federal Elementary and Secondary Education Act (ESEA) program funds, and other non-local revenue. Local and state MFP revenue began rising around 1963 and 1965, respectively, and continued to increase in most years through the mid-1970s. The structure of the state MFP did not change during this period, although some of the parameters of the formula and the total revenue distributed did change. Federal ESEA revenue jumped substantially in 1966 and remained around that level into the 1970s. The combination of these trends meant that total revenue began to increase substantially after 1965, around the time districts took their first steps toward desegregation.

\footnotetext{
${ }^{38}$ Real assessed valuation includes country and city lots and improvements on country and city lots, agricultural lands, timberlands, marshland, and manufacturing plant buildings; country and city real estate and improvements are the largest component of real assessed valuation. Non-real assessed valuation includes public service corporations, manufacturing plants and equipment, inventories, machinery and equipment, business furniture and fixtures, watercraft, aircraft, credits (insurance and finance companies), financial institutions, leasehold improvements, drilling rigs, pipelines, oil and gas equipment, and miscellaneous property. 39 The Minimum Foundation Program (MFP) formula is described in more detail in the Appendix.
} 
Changes in Per-Pupil Revenue by Initial Black. Enrollment Share

In the remainder of this section, I show that increases in per-pupil revenue were substantially larger in higher black enrollment share districts, allowing such districts to "level up" average funding to that previously available only in the white schools and equalize black-white student-teacher ratios without increasing class sizes for whites. I first show that these differential changes were not a gradual trend over a long period but represented a sharp change around the time of desegregation. I then show that the results are not sensitive to controlling for a variety of other pre-existing characteristics of school districts and decompose the revenue changes into more detailed categories.

Figure 7 demonstrates that the relationship between initial black enrollment share and perpupil revenue changed sharply between 1965 and 1970— the period of desegregation. Recall that before desegregation, the relationship between per-pupil total revenue and black enrollment share was negative, due mostly to a negative relationship between per-pupil local revenue and black enrollment share (Figure 3). To see how this relationship changed around the time of desegregation, I regress per-pupil revenue (by source) on 1961 black enrollment share separately for each year between 1955 and 1975. Figure 7 plots these coefficients (each point in the figure is the coefficient from a separate regression)..$^{40}$ Whereas non-local revenue was only weakly (and statistically insignificantly) related to black enrollment share before 1966, by 1970 the relationship became strongly positive, with a statistically significant coefficient of $\$ 1,497$. Blacker districts continued to raise less revenue locally, partially offsetting those districts' higher non-local revenue.

Within a span of five years, therefore, the relationship between a district's black enrollment share and its funding reversed, so that—after desegregation—-high black enrollment share districts received substantially more funding. What explains these substantial disproportionate increases in revenue from state and Federal sources for districts with high black enrollment shares during this period? To what extent do these changes reflect changing state and Federal treatment of race, poverty, or other characteristics of districts?

\footnotetext{
${ }^{40}$ For ease of presentation, Federal and state revenue are aggregated to non-local revenue here; the moredetailed categories are presented in the tables discussed below.
} 
As for changes in enrollment and assessed valuation presented above, I regress the change between 1965 and 1970 in per-pupil revenue by source on the initial black enrollment share alone (equation (1)), and then add controls for several measures of economic status to see whether the correlation between race and economic status explains the disproportionate increase in revenue for blacker districts during this period (equation (2)). The Federal Poverty Line (FLP) had not yet been established before the 1960 Census, so tabulations of poverty rates at the Parish level are not available in the 1960 Census. I therefore use the fraction of households in a Parish without complete plumbing — available in the 1960 Census—and the fraction of households with income below $\$ 3,000$ as a proxies for poverty ${ }^{41}$ as well as per-capita income in the Parish.

The results for changes in total, non-local and local revenue per pupil are reported in Table 4. The results confirm the changes seen in Figure 7: Total revenue per pupil increased substantially and statistically significantly more between 1965 and 1970 for districts with higher black enrollment shares, coming mostly from non-local revenue. ${ }^{42}$ For total revenue, the coefficient on the initial black enrollment share is $\$ 1,453$ without controls, and the estimate is largely unaffected by the inclusion of control variables (columns (1)-(3)). The coefficient is large, suggesting that a district at the $90^{\text {th }}$ percentile of the black enrollment share distribution in 1961 (64 percent black) would have expected to see an increase in total per-pupil revenue that was $\$ 682$ more than that experienced by a district at the $10^{\text {th }}$ percentile (17 percent black), starting from an average of about $\$ 2,700$ in 1965 . The estimates with non-local revenue as the dependent variable show that most of the disproportionate increase in revenue for high black enrollment share districts came from non-local revenue (columns (4)-(6)). For the specifications with controls, the estimates imply that over 75 percent $(1.150 / 1.527)$ of the disproportionate increase in revenue came from non-local sources. I therefore analyze more detailed

\footnotetext{
${ }^{41}$ Somewhat surprisingly, the fraction of households without plumbing continues to vary substantially across Parishes and continues to be a good proxy for poverty in 1970. The fraction of households in a Parish without plumbing is highly correlated with its poverty rate in 1970 (Table 1).

${ }^{42}$ Without the inclusion of controls, the coefficient on initial black enrollment share is simply the change in the coefficient on black enrollment share from 1965 to 1970, as shown in Figure 7 (the black enrollment share for 1961 — early enough to have been plausibly unaffected by desegregation — is used in each of the year-by-year regressions.)
} 
categories of non-local revenue ${ }^{43}$ in Table $5 .{ }^{44}$ Again, the results with and without controls are similar. ${ }^{45}$ The first two columns replicate the results for total non-local revenue shown in Table 4. There was no single source of the disproportionate increase in non-local revenue for blacker districts: The coefficient on black enrollment share was 0.54 for Federal ESEA revenue, 0.52 for the State MFP, and 0.09 for other non-local revenue, indicating that those categories contributed 47, 45, and 8 percent respectively to the disproportionate increase in non-local revenue.

Both the MFP and ESEA aid were distributed based on formulas that did not consider race explicitly, so it is somewhat surprising that the control variables do not change the coefficients on the black enrollment share. ESEA revenues were zero or small for all districts in 1965, as the program had just been authorized; thus, the change from 1965 to 1970 is roughly the same as the 1970 amount which was distributed based on poverty counts (not race). Indeed, in a regression of 1970 ESEA revenue per pupil on the black enrollment share and the 1970 poverty rate (not reported), inclusion of the 1970 poverty rate as a control reduces the coefficient on black share of enrollment to near zero and statistically insignificant, suggesting that poverty—rather than race-explains variation in ESEA revenue across districts in 1970. The correlation of black enrollment share and poverty rates across districts and over time is quite high, so a Parish's black enrollment share is a strong predictor of future poverty rates. The black share of enrollment in 1961 is a significant predictor of 1970 ESEA revenue because it is strongly correlated with 1970 poverty rates, more strongly than other indicators of economic status-per-capita income, the share of households without plumbing,

\footnotetext{
${ }^{43}$ Federal ESEA includes all revenue received through ESEA programs; the largest component is Title I. Other non-local includes revenue received through other state, federal or mixed programs and accounts for about 17 percent of non-local revenue in 1965.

${ }^{44}$ In results not reported, I examined the major components of local revenue-property taxes, sales taxes, and other local taxes - separately. The importance of the sales tax as a source of local revenue increased during this period. In 1965, less than half of Parishes had any sales tax, and the sales tax accounted for only 7.5 percent of local revenue for the average district. By 1970, more than three-quarters of districts has a sales tax, and the sales tax accounted for 26.8 percent of local revenue for the average district. Here, the point estimates depend more on whether controls are included, but it appears that the disproportionate increase in local revenue in blacker districts came roughly equally from changes in sales taxes and local property taxes.

${ }^{45}$ For all regressions reported in Table 5, including the pre-existing trend in the left-hand-side variable also affects the coefficient estimates only slightly (not reported).
} 
and the share of families with income below $\$ 3,000$ — that are available for the early 1960 s. ${ }^{46}$ The

Federal ESEA revenue was, in fact, directed to districts with many children in poverty; but due to the high correlation between racial composition and economic status, blacker districts benefited most from the program. As discussed below, whether these increases in ESEA revenue can be said to be caused by desegregation depends on whether districts and the state would have offset the increase in funding by lowering their own contribution to education in the absence of desegregation.

Aid from the state MFP was also distributed according to a formula that did not include racial composition—or even the economic status—of districts explicitly. Throughout the period under study here, this formula had the same basic structure. The structure of the Minimum Foundation Program is described in more detail and changes in funding from the Program are broken down further in the Appendix. There is no single, identifiable change to the formula that was adjusted to provide more revenue to predominately black districts; instead, such districts benefited at least a little from virtually every change in the calculation of total grants between 1965 and 1970. It would be useful to know the legislative history of the Minimum Foundation Program during this period-information about whether desegregation was discussed in the debate about how to alter the formula could help sort out whether these changes were indeed caused by desegregation or were a response to some other change. Unfortunately, the budget process in Louisiana at this time was secretive, and there are no records of legislative debates for this period. ${ }^{47} \mathrm{I}$ argue below that it is likely that the increased funding was caused—at least in part—by desegregation, as it was needed to prevent whites in high black enrollment share districts from seeing their class sizes rise in integrated schools. I now turn to the effects of desegregation on student-teacher ratios by race. Spending the New Money: Changes in Student-Teacher Ratios

\footnotetext{
${ }^{46}$ In a multivariate regression of 1970 poverty rate on all of the control variables in Table 5, the black share of enrollment is by far the most significant.

${ }^{47}$ For example, an article in the New Orleans States-Item on June 14, 1969 complains that "the Budget Committee, whose financing was raised from $\$ 80,000$ to $\$ 116,000$ a year, meets in secret on important and controversial issues ... and then expects the public to swallow as fact whatever it deigns to reveal about the state's fiscal situation." I am grateful to Marc Wellman at the Louisiana State Library for bringing this article to my attention and help researching the records - or lack thereof - of deliberations of the Legislature and the Budget Committee.
} 
The analysis so far has focused on changes in the distribution of revenues among districts with higher and lower black enrollment shares, showing that after desegregation resources were increasingly directed to districts with many blacks. To assess how resources for the average black and the average white student in Louisiana changed, we also need to know something about how the allocation of resources changed within districts.

Was the additional revenue raised in predominately black districts enough to prevent whites from seeing their class sizes increase? Once students and teachers were no longer segregated by race (after 1965), the number of students and teachers by race at the district level cannot be used to estimate the student-teacher ratios that blacks and whites actually experienced. To estimate the average student-teacher ratio experienced in schools attended by blacks and whites in 1970, I use school level data on the number of students and teachers collected by the Office of Civil Rights (OCR). ${ }^{48}$ I then calculate the change in student-teacher ratios by race and overall from $1965^{49}$ to 1970 and examine how this relates to the initial black enrollment share, as for enrollment and per-pupil revenue above.

Recall that if additional resources had not been disproportionately made available to heavily black districts, whites in those districts would have seen their class sizes rise, relative to whites in less black districts due to the large gap between the white student-teacher ratio and the average studentteacher ratio. As a baseline, it is useful to see how student-teacher ratios for whites would have changed if no new teachers were hired but schools were integrated so that whites experienced that district average student-teacher ratio. Regressing the 1965 average student-teacher ratio less white student-teacher ratio on 1961 black enrollment share yields a coefficient of 6.8 ( $p$-value $<0.001$ ) (results not reported). For example, whites in a district that was 80 percent black would expect to see

\footnotetext{
${ }^{48}$ It is possible, of course, that within-school inequality of class size rose with desegregation, especially through tracking at the high school level.

${ }^{49}$ Recall that students and teachers were still completely segregated, so the student-teacher ratio for blacks is the total number of blacks in the district divided by the total number of black teachers (and similarly for whites).
} 
their student-teacher ratio increase by about 4 students more than whites in a district that was 20

percent black $(6.8 * 0.6)$.

Table 6 shows that the relative increases in white student-teacher ratios for heavily black districts were not nearly so large. The table presents the results of estimating equations (1) and (2) for the average, black, and white student-teacher ratios. Average student-teacher ratios (for blacks and whites together) fell significantly more between 1965 and 1970 in districts with high black enrollment shares—-suggesting that high-black-enrollment-share districts used at least some of their disproportionate increases in funding to hire more teachers.

The coefficients of 1.9 and 1.0 (columns (3) and (4)) indicate that whites in higher black enrollment share districts did see larger increases in their student-teacher ratios than their white counterparts in "whiter" districts, although the coefficient is only marginally significant in one of the specifications. On the other hand, student-teacher ratios experienced by blacks fell dramatically more in high black enrollment share districts (columns (5) and (6)). These results suggest that the new revenue directed to high black enrollment share districts was used to "level up" quality for blacks close to that formerly experienced by whites in the same district.

It is interesting to note that before desegregation, there was significant inequality between districts in spending on whites, with whites in high black enrollment share districts experiencing smaller student-teacher ratios. After desegregation, this within-race, between-district inequality remained, but students in high black enrollment share districts of both races had smaller studentteacher ratios. ${ }^{50}$

\footnotetext{
${ }^{50}$ As mentioned above, Card and Krueger (1992), Margo (1990), and others have shown that black-white inequality of school quality in the South had narrowed substantially before desegregation. Consistent with Card and Krueger's work, the data from the Annual Financial and Statistical Reports show that student-teacher ratios for both races were declining rapidly in the 1950s, and the black-white gap was closing somewhat. The decline for blacks accelerated around 1964, when there was still virtually no desegregation. Anecdotal accounts suggest that before Green (1968), whites hoped that improving resources for blacks might fend off more stringent desegregation, which may account for the acceleration in 1964. In addition, ESEA programs were most likely more often implemented in black schools, as black students had higher poverty rates. Student-teacher ratios for whites, on the other hand, declined relatively steadily between 1955 and 1965; and assuming whites had a student-teacher ratio near the average student-teacher ratio after 1970, the decline continued unperturbed through 1975. Over the longer term, other forces were probably more important than desegregation in reducing black-white school quality gaps (although the threat of desegregation may have contributed). Still, the
} 


\section{Discussion: The Flypaper Effect and Alternative Explanations}

Without an appropriate control state similar to Louisiana that did not integrate its schools, it is difficult to make strong statements about whether the changes in financing described here were caused by—or simply coincident with—desegregation. However, an understanding of the preexisting system of school finance and the ability to decompose changes into detailed revenue categories help to assess the causal contribution of desegregation policy to the observed changes in school finance between 1965 and 1970.

I discuss the likelihood that the increases in Federal and state revenue were caused by desegregation in turn. ESEA was distributed to districts with economically disadvantaged students. Given the strong correlation between race and poverty in Louisiana, districts with high black enrollment shares would have received such funds even in the absence of desegregation. Thus, one might argue that the increase in ESEA funding was caused by desegregation only insofar as the Civil Rights Act prohibited segregated districts from receiving such funds. However, local districts or the state might have been expected to offset—at least partially—increased revenue from the Federal government with reductions in revenue from other sources. Quite the opposite, immediately following the introduction and expansion of ESEA, the state government and school districts increased their support for schools further, especially in those districts that had just garnered the largest ESEA increases.

On the other hand, a substantial literature documents so-called "fly-paper effects" for federal aid to lower levels of government: While neoclassical models of local government behavior would suggest that school districts would spend Federal grants for education as they would any other income (so increasing school spending by only a fraction of the grant) ${ }^{51}$, the literature suggests that

period of desegregation in Louisiana does appear to have finally ended the Jim-Crow era system of school finance in the state.

51 According to provisions of ESEA, school districts and the state were technically prohibited from reducing their own spending on schools in response to receipt of funds under the program, and their were some

"maintenance of effort" requirements in the law. Such requirements are difficult to enforce (especially when spending is trending up, since local governments could simply reduce the rate at which they increase their own spending, offsetting the Federal grant over time.) 
Federal aid "sticks where it hits." Local governments tend not to fully offset increases in Federal aid with reductions in local revenue; estimates in the literature suggest that for every additional dollar of Federal aid school districts receive, they spend an additional $\$ 0.25$ to $\$ 1$ on education. 52

In any case, the flypaper effect suggests that local governments do not reduce their own revenue for education as much as expected given their marginal propensity to spend on education out of regular income. However, it does not suggest that local governments (in this case the state) would increase their own spending on education in response to receiving a grant, as Louisiana did following the introduction of ESEA. (The observed behavior of state funding in Louisiana would yield flypaper estimates on the order of 2 , well outside the range in the literature.)

While we cannot know whether state and local revenue would have been increased more in the absence of ESEA, the fact that new ESEA revenue was not offset by lower state and local revenue but was instead followed by a large increase in state revenue suggests that districts' demand for revenue was increasing. This points to a general increase in demand for resources in those districts to which the legislature responded, if not transparently. ${ }^{53}$ Given the large increases in class size_-after years of decline_- that whites in heavily black districts would have seen in integrated schools, it is plausible that the state would be persuaded to increase aid to such districts, and the disproportionate increase in revenue from the MFP was probably at least in part caused by desegregation.

Alternative explanations for the disproportionate increase in funding for higher black enrollment share districts include changing preferences for spending on black students relative to whites, the possibility that ESEA funding was not fungible, and increased voting by blacks following the Voting Rights Act of 1965. Given the persistent resistance to desegregation and other Civil Rights policies in the state, it seems unlikely that changing attitudes explain the observed changes in

${ }^{52}$ See Hines and Thaler (1995) for a review of the literature on the flypaper effect generally and Fisher and Papke (2000) for a review of the flypaper effect in education. See Gordon (2004) for the best-identified estimates of the effect of Title I grants on expenditure.

${ }^{53}$ As discussed above, it would be interesting to examine the records of the legislative debate at the time the formula was changed. Unfortunately, such records are not available. 
funding, although I cannot rule it out. There were some restrictions on how ESEA revenue could be spent (although these regulations were poorly enforced in the early years of the program). This lack of fungibility could explain why districts and the state did not offset ESEA revenue by reducing their own support. Still, this does not explain the increase in state funding between 1968 and 1970, and the additional revenue appears to have been largely devoted to equalizing black and white studentteacher ratios.

Increased voting is the most plausible alternative explanation, as blacks gained political power, they may have been able to direct more state funding to heavily black districts. Adding controls for the change from 1964 to 1968 in the share of the black voting-age population registered to vote in each county, collected by Matthews and Prothro (1963a, 1963b), does not alter the coefficients on black enrollment share much. This is an admittedly imperfect measure of the change in black voting or political influence overall. However, even considering that voting among blacks did increase substantially during this period, it is unclear whether blacks would have gained enough influence in the state legislature to bring additional revenue to their districts. Still, it is possible that it was the combination of Civil Rights and War on Poverty policies—desegregation, the Civil Rights Act, the Voting Rights Act, and the Elementary and Secondary Education Act—-that produced these changes in Louisiana's school finance system.

\section{Conclusions}

One motivation for integrating public schools was a concern that black schoolchildren would never receive adequate resources in their schools so long as they were separate from whites. It was hoped that whites would support higher spending for the schools attended by blacks if their children attended those same schools. The financing of schools in Louisiana had long advantaged whites relative to blacks and whites in "blacker" districts relative to whites in "whiter" districts. Because of this system, whites in districts with high black enrollment shares stood to lose the most from desegregation, as the gap between white student-teacher ratios and the district average student-

teacher ratios in those districts was higher. Given the importance of districts' black enrollment share 
in the system of finance and the potential impact of desegregation, I examine how changes in public and private enrollment, the local property tax base, and per-pupil revenue relate to the initial black enrollment share. The analysis suggests that the Jim-Crow system of school finance finally unraveled as the schools desegregated.

Desegregation of Louisiana's schools was associated with a shift of white enrollment from public to private schools and from blacker to whiter public school districts. This decline in public enrollment offset relative reductions in the local property tax base in districts with high black enrollment shares, preventing a falloff in local revenues. During the period that Louisiana school districts integrated, large increases in funding from all sources were disproportionately directed to districts with higher black shares of enrollment, allowing the quality of desegregated schools to be "leveled up" to that previously experienced in the white schools, rather than falling closer to the quality of the segregated black schools. In other work (Reber 2006), I find evidence that blacks' educational attainment also rose more in high black enrollment share districts during this period, suggesting the increased resources devoted to blacks' education during this period of desegregation also improved their educational outcomes. Together, these papers suggest that desegregation was successful in the goals of reducing segregation, reducing black-white inequality of resources, and improving educational outcomes. 


\section{References}

Alexander, S. K. (1967). Public School Finance Programs, 1966-1967. Washington, D.C., U.S. Department of Health, Education, and Welfare.

Bell, D.A. (2004). Silent Covenants: Brown v. Board of Education and the Unfulfilled Hopes for Racial Reform. Oxford University Press.

Bond, Horace Mann. (1934). The Education of the Negro in the American Social Order. New York, Prentice-Hall.

Boozer, M. A., A. B. Krueger, et al. (1992). "Race and School Quality since Brown v. Board of Education.” Brookings Papers on Economic Activity, Microeconomics: 269-326.

Card, D. and A. B. Krueger (1992). "School Quality and Black-White Relative Earnings: A Direct Assessment.” Quarterly Journal of Economics: 107(1): 151-200.

Cashin, S. (2004). The Failures of Integration: How Race and Class Are Undermining the American Dream. New York. PublicAffairs.

Clotfelter, C.T. (2004). After Brown: The Rise and Retreat of School Desegregation. Princeton. Princeton University Press.

Clotfelter, C.T. (1975). “The Effect of School Desegregation on Housing Prices,” Review of Economics and Statistics. 57: 446-451.

Coleman, J. S. (1966). Equality of Educational Opportunity Summary Report. Washington, D.C., U.S. Dept. of Health, Education, and Welfare, Office of Education.

Cottol, R.J., R.T. Diamond, L.B. Ware (2003). Brown vs. Board of Education: Caste, Culture, and the Constitution. Lawrence, Kansas. University of Kansas Press.

Fisher, R. C. and L. E. Papke (2000), “Local Government Responses to Education Grants,” National Tax Journal, 53(1): 153-68.

Gordon, N., "Do Federal Grants Boost School Spending? Evidence from Title I," Journal of Public Economics: 88(9-10): 1771-1792.

Greenberg, J. (1994). Crusaders in the Courts: How a Dedicated Band of Lawyers Fought for the Civil Rights Revolution. New York. BasicBooks.

Guryan, J. (2004). "Desegregation and Black Dropout Rates," American Economic Review, September 94(4): 919-943.

Hines, J. R. J. and R. H. Thaler (1995). “The Flypaper Effect.” Journal of Economic Perspectives 9(4): 217-26.

Johns, T. L. (1969). Public School Finance Programs, 1968-69. Washington, D.C., U.S. Department of Health, Education, and Welfare.

Johns, T. L. (1972). Public School Finance Programs, 1971-72. Washington, D.C, Department of Health, Education, and Welfare. 
Kousser, J.M. (1980). "Making Separate Equal: The Integration of Black and White School Funds in Kentucky," Journal of Interdisciplinary History. 10(3): 399-428.

Kousser, J.M. (1991). "Before Plessy, Before Brown: The Development of the Law of Racial Integration in Louisiana and Kansas," in Paul Finkelman and Stephen C. Gottlieb, eds., Toward A Usable Past: Liberty Under State Governments; Athens, GA: University of Georgia Press: 213-70.

Lynch, Bill. “Legislature: Study in Contrasts.” New Orleans States-Item. June 14, 1969.

Margo, R. A. (1990). Race and schooling in the South, 1880-1950: An economic history. Chicago and London, University of Chicago Press.

Matthews, D. R. and J. W. Prothro (1963a). "Social and Economic Factors and Negro Registration in the South," American Political Science Review. 57(1): 24-44.

Matthews, D. R. and J. W. Prothro (1963b). "Political Factors and Negro Voter Registration in the South," American Political Science Review. 57(2): 355-367.

Munse, A. A. (1965). State Programs for Public School Support. Washington, D.C., U.S. Department of Health, Education, and Welfare, Office of Education.

Ogletree, C.J. (2004). All Deliberate Speed. New York and London: W. W. Norton \& Company.

Orfield, G. (1975). Congressional Power: Congress and Social Change. Harcourt Brace Jovanavich.

Reber, S. J. (2005). "Court-Ordered Desegregation: Successes and Failures in Integration since Brown vs. Board of Education." Journal of Human Resources, Summer.

Reber, S. J. (2006). “Desegregation and Educational Attainment for Blacks,” Mimeo.

Ryan, J. E. (1999). “Schools, Race, and Money.” Yale Law Journal 109: 249-316.

Shipp, D. E. and C. W. Hilton (1962). School Finance in Louisiana: A Handbook on Local, State, and Federal School Finance in Louisiana. Baton Rouge, Louisiana Education Research Association.

Shipp, D. E., C. W. Hilton, et al. (1966). School Finance in Louisiana: A Handbook on Local, State, and Federal School Finance in Louisiana. Baton Rouge, Louisiana Education Research Association.

Southern Education Reporting Service (1967). Statistical Summary, State by State, of School Segregation-Desegregation in the Southern and Border Area from 1954 to the Present. Nashville, Tennessee, SERS. 


\section{Appendix: Detailed Analysis of Public School Fund Changes}

A district's allocation from the MFP (Minimum Foundation Program) was its "program

cost" less its required support, both of which were calculated based on formulas:

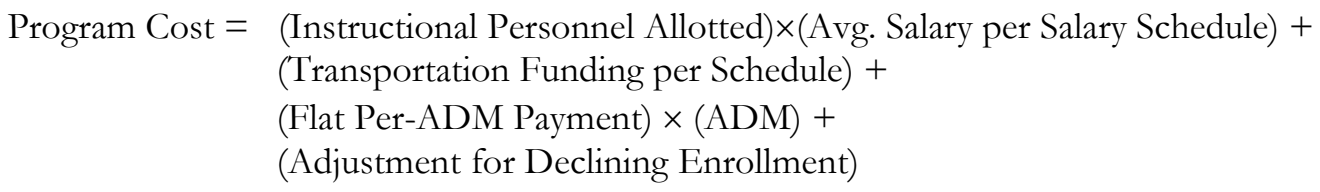

\section{Required Support $=(5$ Mill Constitutional Tax $) *($ Assessed Valuation $)+$ (Severance Tax Collections) + \\ (50\% of Revenue from Rent or Lease of School Lands)}

This overall structure of the formula was not changed between 1961 and 1975, although several of the parameters did change. Instructional personnel were allotted school-by-school, based on enrollment and then aggregated to the district level; ${ }^{54}$ the salary schedule—which depended on education and experience-was then applied to the personnel actually employed. ${ }^{55}$ The allotment for transportation depended on one-way miles traveled, the type of vehicles used and the bus driver salary schedule. Districts also received a flat per-pupil grant for other costs. ${ }^{56}$ Finally, in some years an adjustment was added to program costs for districts with declining enrollment, presumably to ease the transition to lower enrollment. ${ }^{57}$

In terms of required support, the proceeds from the 5 Mill Constitutional Tax depend directly on the local property tax base. The severance tax is paid to a Parish when certain natural resources (such as minerals) are harvested. Proceeds from this tax, as well as from rent or lease of

\footnotetext{
${ }^{54}$ The district was not required to employ the number of teachers allotted to a school in that school; they could distribute their allotted teachers across the district as they saw fit.

${ }^{55}$ Teachers, supervisors, and visiting teachers were actually allotted separately. Supervisor and visiting teacher salaries did not depend on education and experience. I combine the three categories for ease of exposition; expenses for instructional personnel are primarily for teachers. There was a single salary schedule for black and white teachers.

56 Technically, districts receive a small "per-educable" distribution from the Public School Fund based on the number of educable students in the district (including those in private schools); this payment is then considered part of required support for purposed of the Minimum Foundation Program. Since these payments cancel out from the perspective of the Public School Fund as a whole, I exclude it here.

57 There were sometimes other adjustments when a district was under- or over-paid in the previous year. These were small, so I exclude them here.
} 
school lands, depend on the natural resources in the Parish and are relatively small for most Parishes. ${ }^{58}$

Both the schedules used in calculating the programs costs (set by the state)—such as the teacher salary schedule and the number of teachers allotted for schools of different sizes—and the inputs districts employed—such as the education and experience of teachers and the number of miles students are transported—influenced a district's program cost. Both could have affected districts with different black enrollment shares differently. Ideally, I would separate the effects of changes in the formula from changes in inputs to the formula by recalculating the 1970 allocation using the formula in effect in 1965 and comparing this to the actual allocation-the difference could then be attributed to changes in the inputs. ${ }^{59}$ Unfortunately, not all the information needed to apply the school finance formula is available in the Annual Financial and Statistical Report. Still, more-detailed data on districts' revenue from the MFP are available, and I use these to assess whether changes in the formula (schedules), changes in inputs chosen by districts, or both account for the disproportionate increase in revenue from this source for high-black-enrollment-share districts. Table 7 presents a decomposition for per-pupil MFP revenue of the coefficient on initial black enrollment share in each year and the change in that coefficient into the parts attributable to program costs and required contributions. ${ }^{60}$

There is no single component of the formula that was adjusted to provide more revenue to predominately black districts; instead, such districts benefited at least a little from virtually every change in the calculation of total costs between 1965 and 1970. Allotments for salaries (number of personnel allotted $\times$ average salary), transportation, and the declining enrollment adjustments all contributed to the disproportionate increase in revenue from the MFP, accounting for 55, 26, and 23 percent of the change, respectively. In fact, these program-cost-side categories account for more than

\footnotetext{
${ }^{58}$ As noted above, oil was discovered on Cameron Parish School District property, so its revenue from the rental of these lands was quite high.

59 Alternatively, one could evaluate the 1965 and 1970 formulas, holding inputs constant at their 1965 values. ${ }^{60}$ Each Annual Financial and Statistical Report presents detail on Minimum Foundation Program allotments for the following school year. "Other Adjustments" is the difference in the allotment reported in the main revenue table and the amount reported in the MFP detailed table of the previous year's report.
} 
100 percent of the increase (112 percent), as required support also increased somewhat more in blacker districts (reducing payments from the MFP).

The allotment for instructional personnel increased more in high-black-enrollment-share districts for two reasons: First, the number of teachers allotted per student grew more in those districts. The teacher allotment schedule changed so that relatively large elementary schools were allotted more teachers. I do not have information on the school size, but this finding suggests that blacker districts had larger schools and therefore benefited more from this provision. Second, average salaries increased more in high-black-enrollment share districts, who employed moreexperienced and better-educated teachers before desegregation and saw bigger increases in both the average education and experience of their teachers between 1965 and 1970, relative to whiter districts. The average return to experience in the salary schedule actually fell slightly, but this was more than offset by the higher experience and educational attainment and increases in the return to education in high-black-enrollment-share districts.

Some of these increases are expected to be temporary (for example, the declining enrollment adjustment). However, the coefficient on initial percent black in the MFP regression remained large and positive through the 1970s (not reported), and the change from 1965 to 1973 (last column of Table 7) is similar to that from 1965 to 1970 . The changes in MFP funding were maintained for some time after desegregation. Unfortunately, the decomposition of changes in MFP funding do not point to a single, identifiable change that was clearly designed to help districts with higher black enrollment shares. Nevertheless, the sum of many changes added up to the large disproportionate increases for "blacker" districts. 
Figure 1. Trends in Segregation, Louisiana School Districts

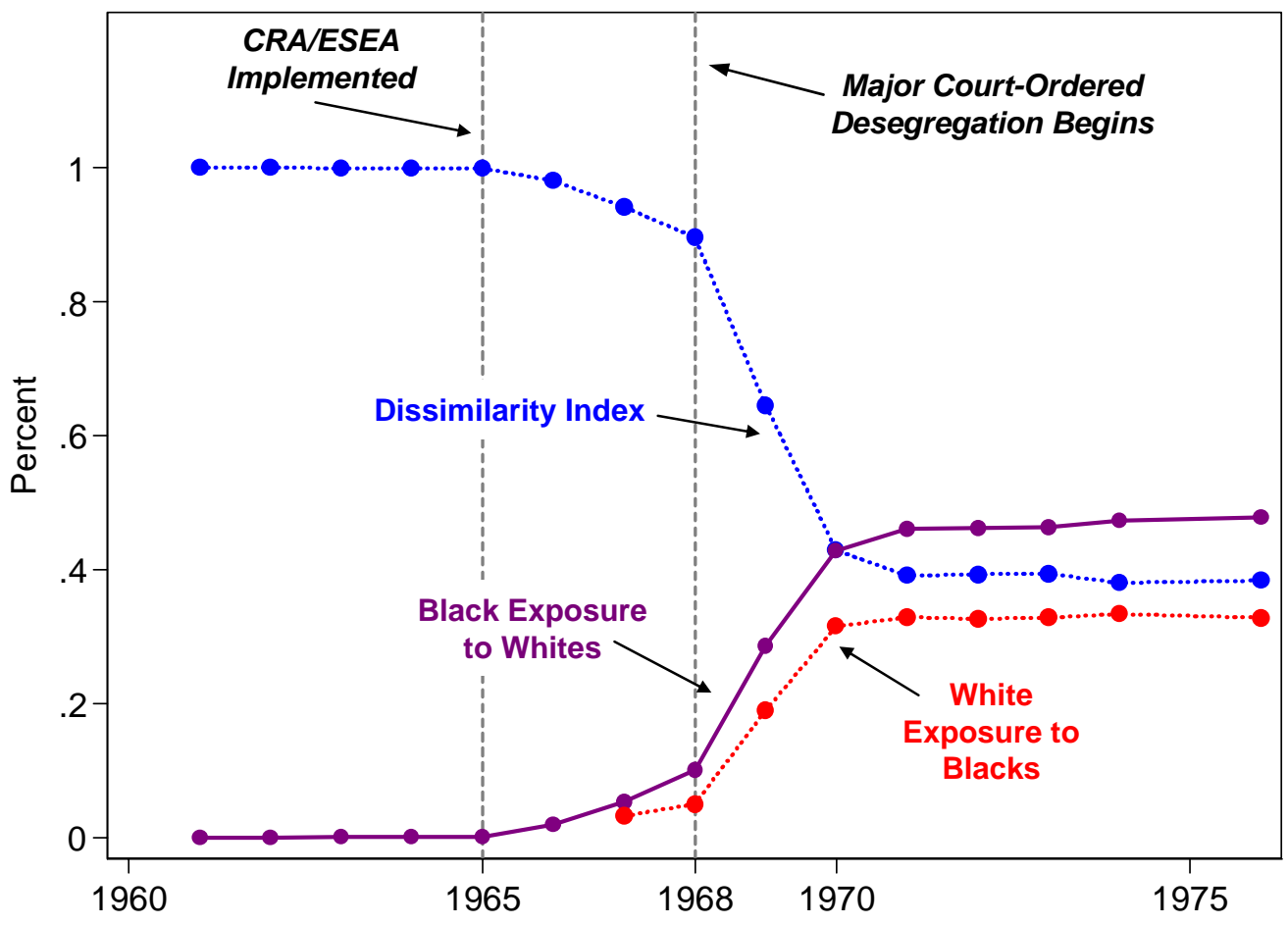

Notes: Authors calculations based on U.S. Department of Health Education and Welfare Office of Civil Rights data (1967-76) Southern Education Reporting Survey data (196166). Trends are reported for all Parishes, but are similar if sample is limited to the 47 Parishes with data available in all years reported. Dissimilarity index is calculated for blacks and whites. 
Figure 2. Initial Black Enrollment Share and Whites' Exposure to Blacks

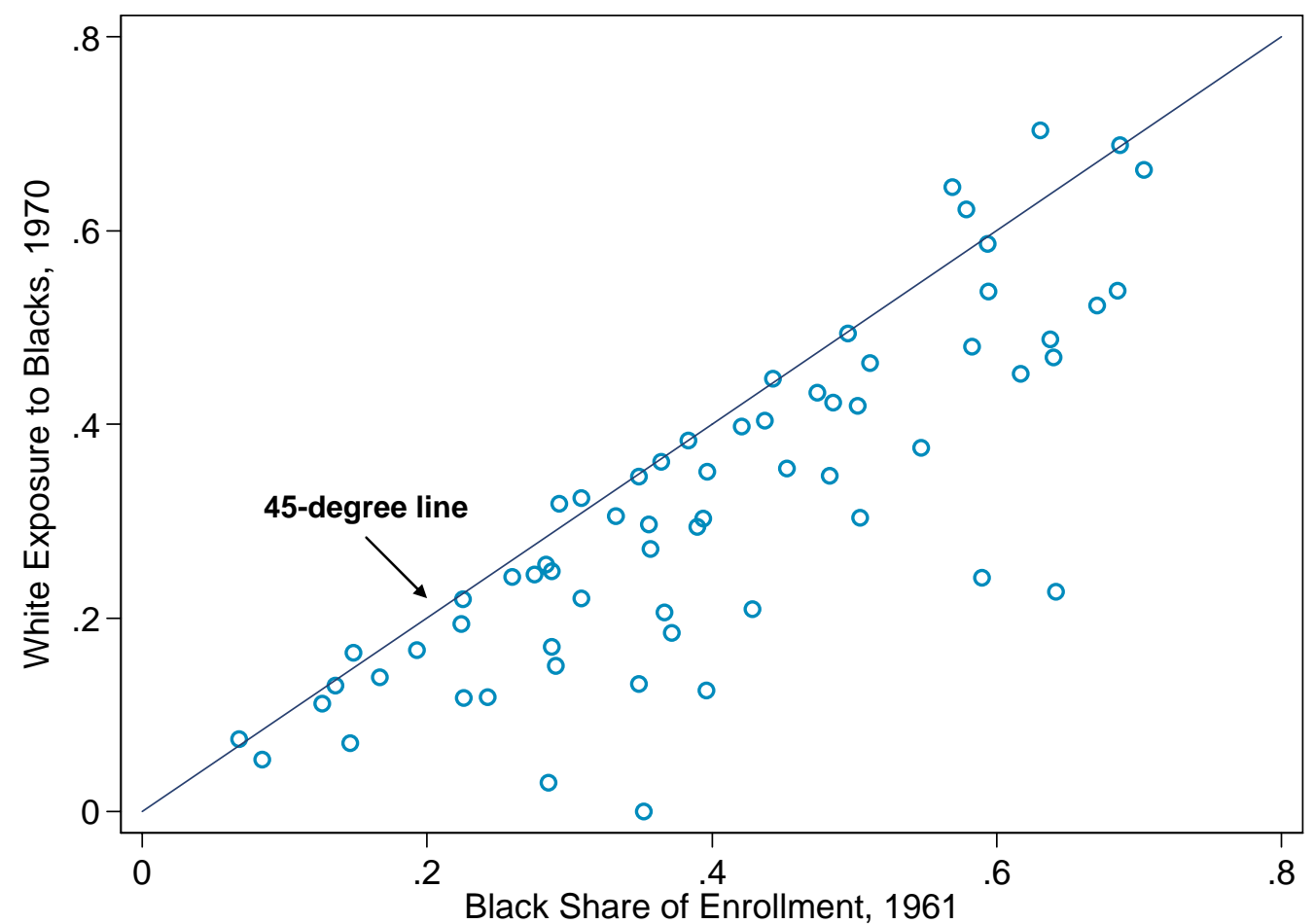

Notes: Black share of enrollment from Louisiana Department of Education Annual Financial and Statistical Report. Change in white exposure to blacks calculated from U.S. Department of Health Education and Welfare Office of Civil Rights data. 
Figure 3. Black Enrollment Share vs. Per-pupil Revenue by Source, 1961
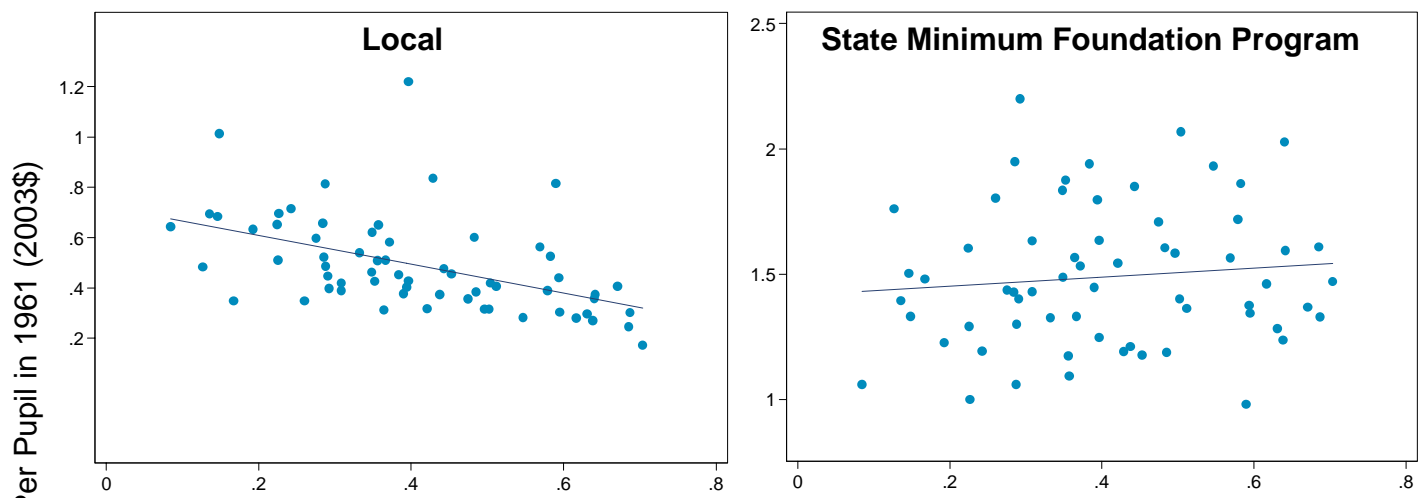

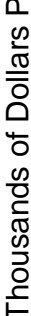
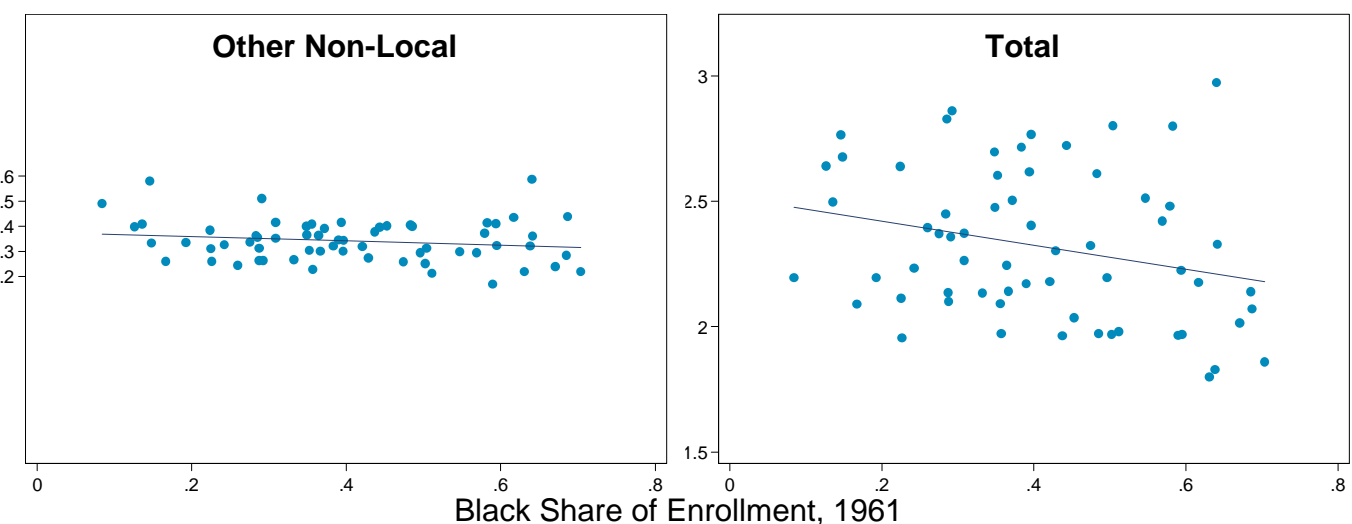

Notes: Author's calculations based on Louisiana Department of Education Annual Financial and Statistical Report. Revenue per registered student in grades K-12 is reported. Cameron Parish excluded. 
Figure 4. Student-Teacher Ratios for Black and White Schools, 1961
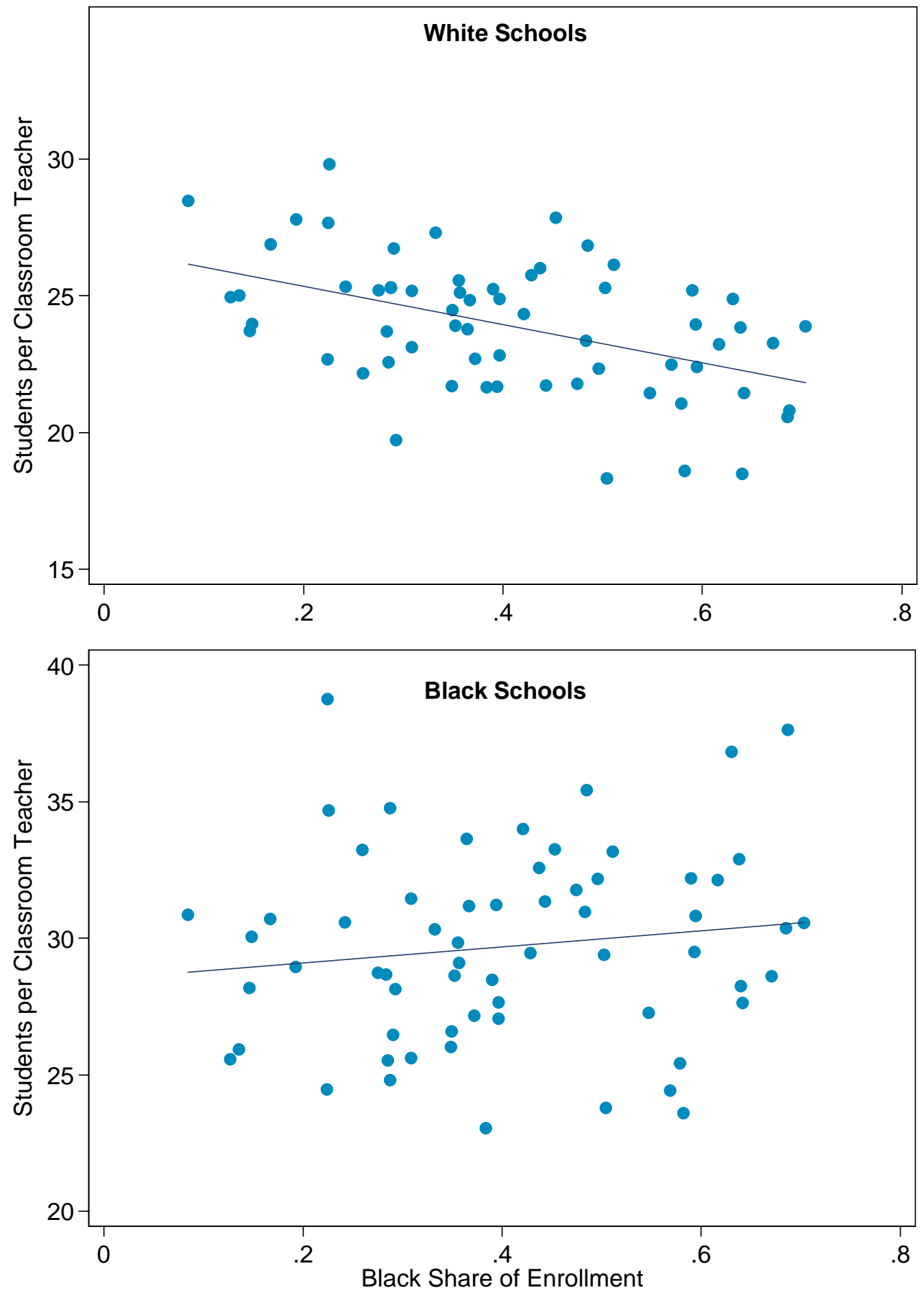

Notes: Author's calculations based on Louisiana Department of Education Amnual

Financial and Statistical Report. In 1961, students and faculty were segregated by race.

Students per classroom teacher for white schools is the total number of white classroom teachers in the district divided by the total number of white students; students per classroom teacher for black schools is calculated similarly. 
Figure 5. Public and Private Enrollment by Race, Louisiana

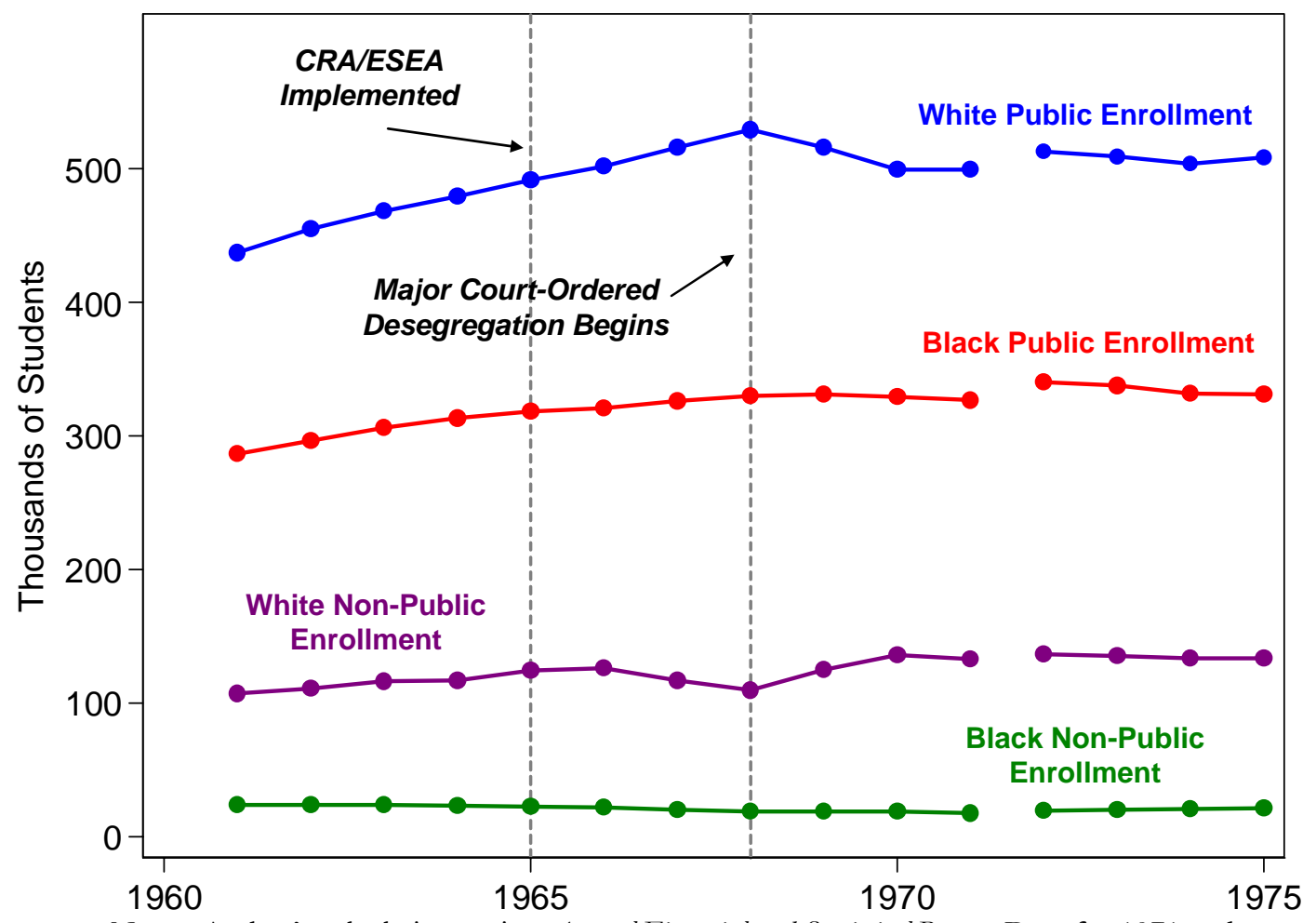

Notes: Author's calculations using Annual Financial and Statistical Report. Data for 1971 and earlier are fall registration for grades 1-12; 1972 and later data are fall registration for grades $\mathrm{K}-12$. 
Figure 6. Trends in Per-Pupil Revenue, by Source

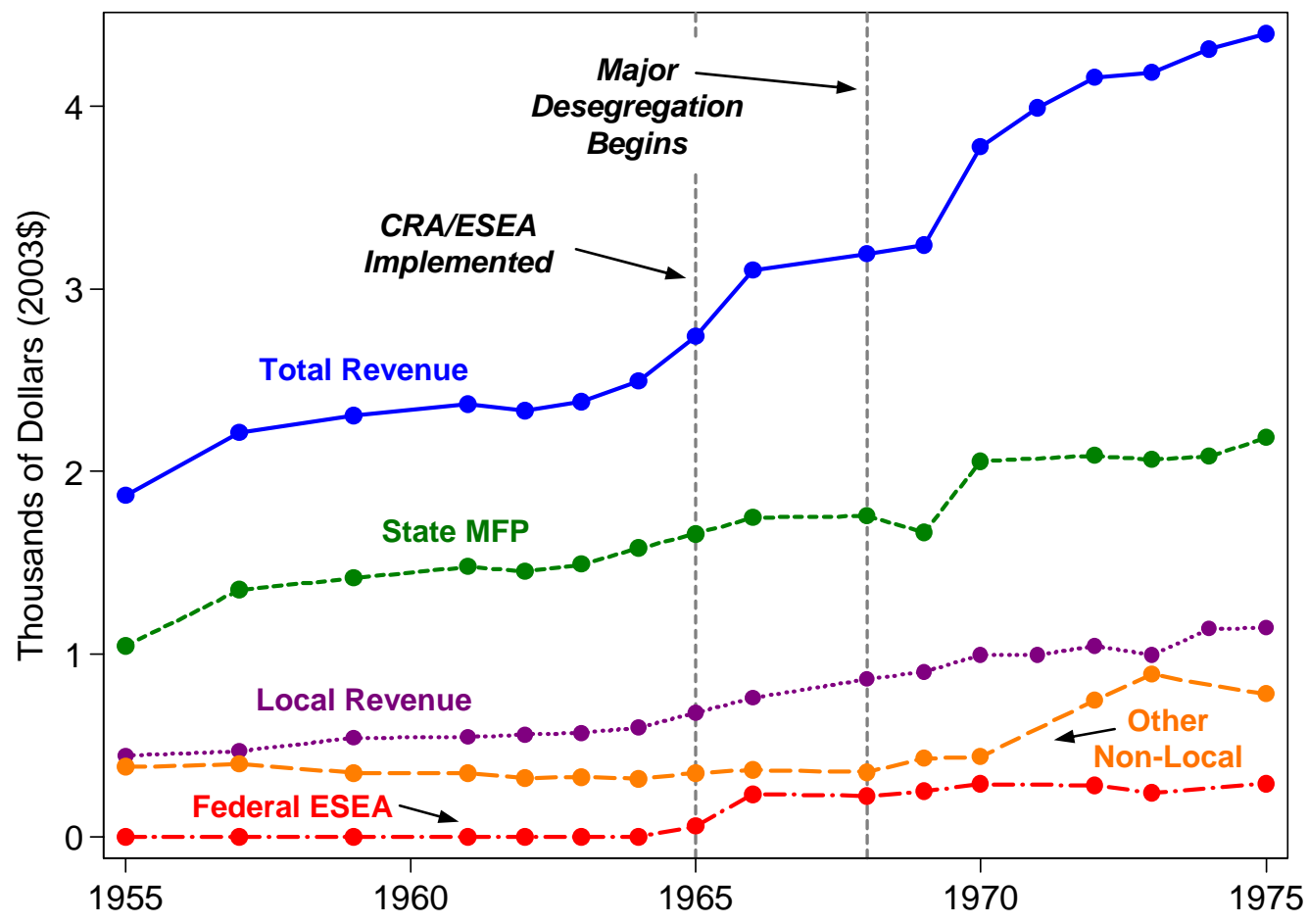

Notes: Author's calculations based on Louisiana Department of Education Annual Financial and Statistical Report. Average revenue per registered student in grades K-12 is reported. 
Figure 7. Coefficient on Initial Black Enrollment Share, by Year

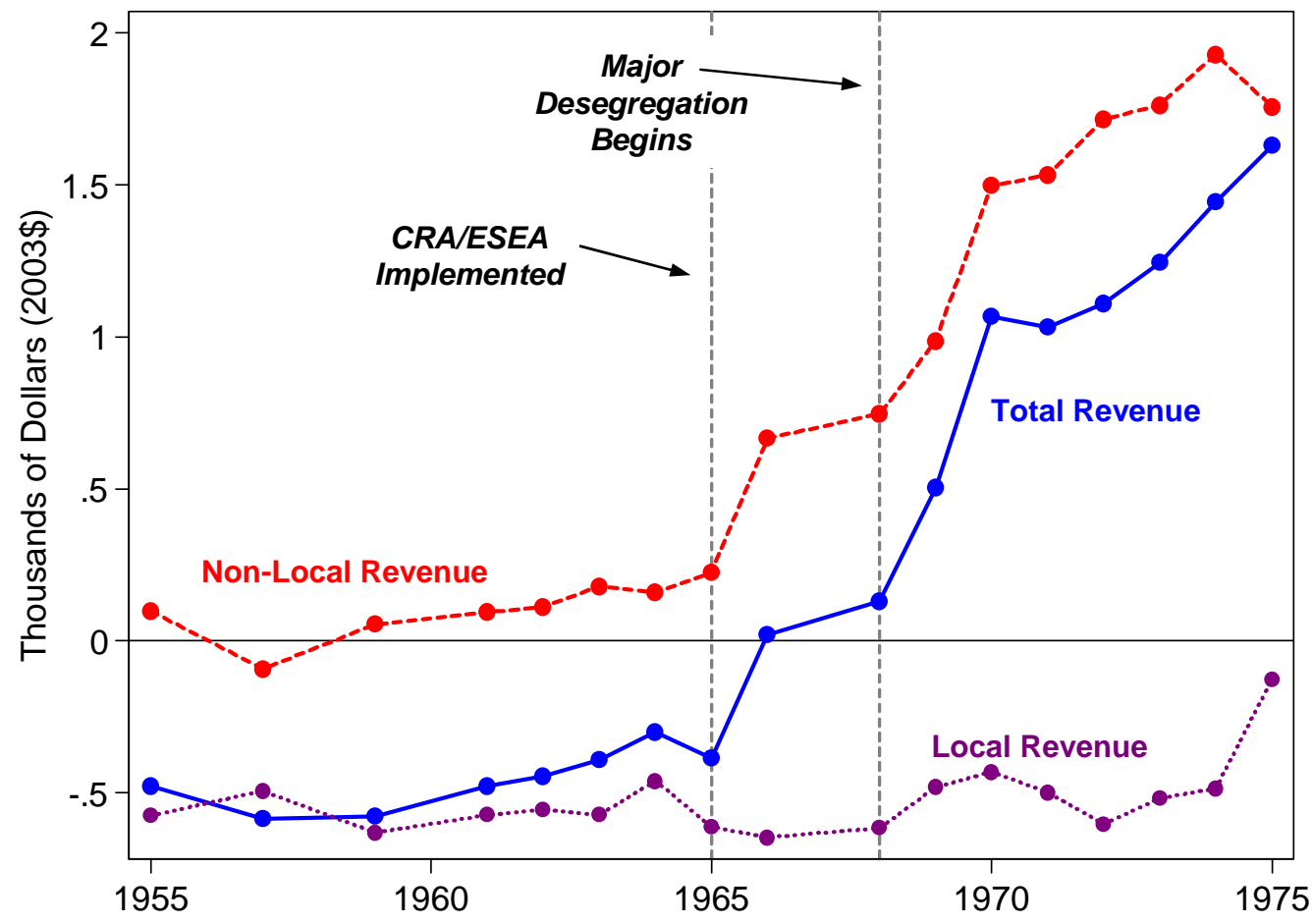

Notes: Chart plots coefficients from univariate year-by-year regressions of total, local, and nonlocal per-pupil revenue on the 1961 black share of enrollment in. Cameron Parish excluded. 
Figure 8. Trends in Average Student-Teacher Ratios, by Race

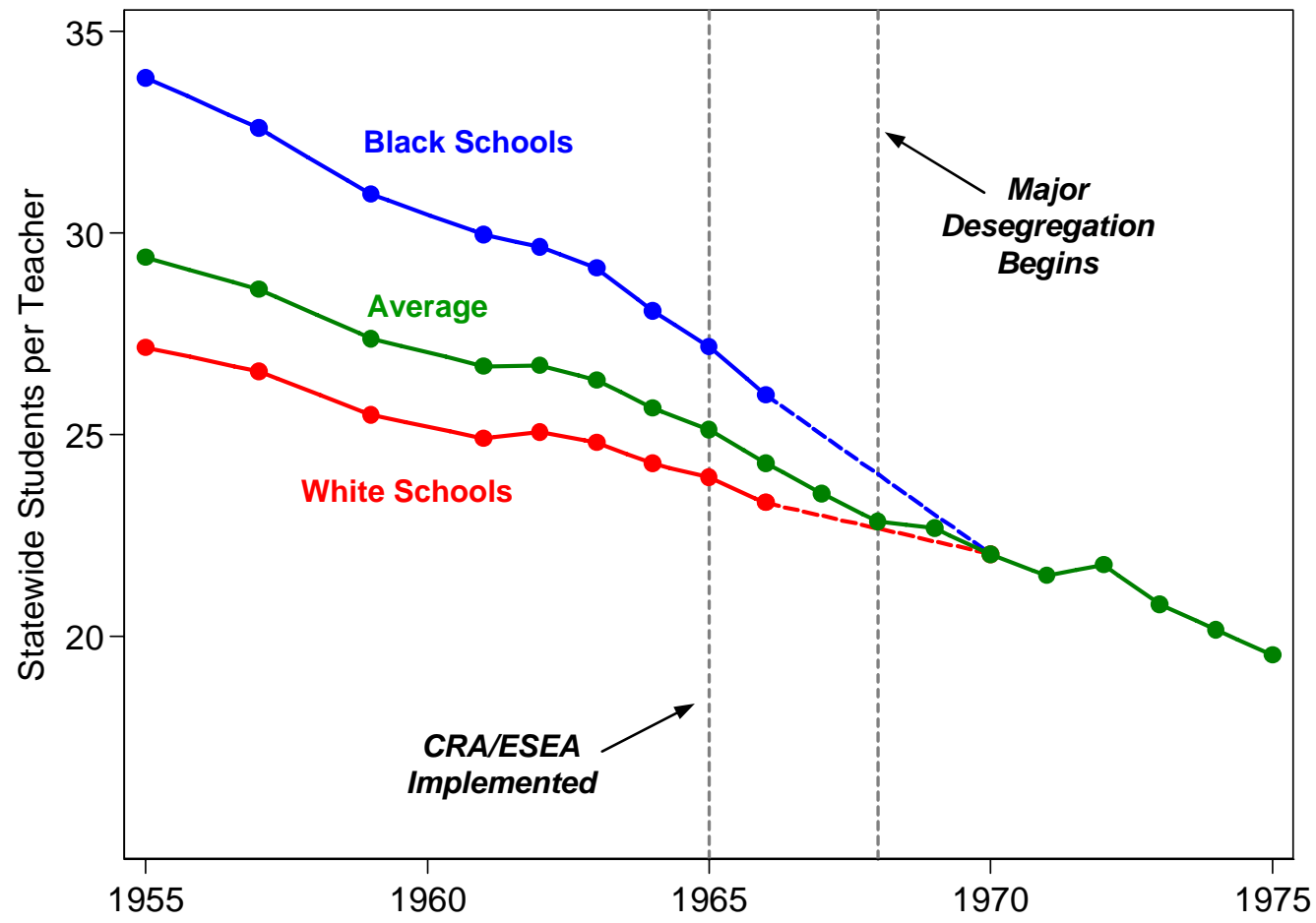

Notes: Author's calculations based on Louisiana Department of Education Annual Financial and Statistical Report. 
Table 1. Correlation of Parish Poverty Measures and Black Enrollment Share, 1970

\begin{tabular}{lcccc}
\hline & \% Black & $\%$ Plumbing & $\%$ Below FPL & Per Capita Inc \\
\% Plumbing & -0.7145 & & \\
$\%$ Below FPL & 0.6405 & -0.7593 & & \\
Per Capita Income & -0.5689 & 0.8649 & -0.8477 & \\
$\%$ Urban & -0.1613 & 0.6174 & -0.4918 & 0.6985 \\
\hline
\end{tabular}

Notes: Correlations for 64 Louisiana Parishes are reported. Percent black is the black share of school enrollment. Percent with plumbing, percent below the Federal Poverty Line, and per-capita income are from the 1970 Census county tabulations. 
Table 2. Correlates of Change in Public and Private Enrollment (1965/66 to 1970/71)

\begin{tabular}{|c|c|c|c|c|c|c|c|c|c|c|}
\hline & \multicolumn{3}{|c|}{$\begin{array}{c}\text { White } \\
\text { Ln (Public Enrollment) }\end{array}$} & \multicolumn{3}{|c|}{$\begin{array}{c}\text { White } \\
\text { Ln(Public }+ \text { Private Enrollment }) \\
\end{array}$} & \multicolumn{2}{|c|}{$\begin{array}{c}\text { White } \\
\text { Percent Private }\end{array}$} & \multicolumn{2}{|c|}{$\begin{array}{l}\text { White and Black } \\
\text { Ln (Total Public) }\end{array}$} \\
\hline & (1) & $(2)$ & (3) & (4) & (5) & (6) & $(7)$ & (8) & $(9)$ & $(10)$ \\
\hline Black Share of Enrollment (1961/62) - & $\begin{array}{c}-1.108^{* * *} \\
(0.141)\end{array}$ & $\begin{array}{c}-1.203^{* * *} \\
(0.177)\end{array}$ & $\begin{array}{c}-1.134 * * * \\
(0.209)\end{array}$ & $\begin{array}{c}-0.521 * * * \\
(0.111)\end{array}$ & $\begin{array}{c}-0.637 * * * \\
(0.146)\end{array}$ & $\begin{array}{c}-0.605^{* * *} \\
(0.179)\end{array}$ & $\begin{array}{c}0.452^{* * *} \\
(0.090)\end{array}$ & $\begin{array}{c}0.442^{* * *} \\
(0.117)\end{array}$ & $\begin{array}{c}-0.609 * * * \\
(0.098)\end{array}$ & $\begin{array}{c}-0.672^{* * *} \\
(0.150)\end{array}$ \\
\hline Per Capita Income (\$1000s) (1959) & & $\begin{array}{l}-0.065 \\
(0.050)\end{array}$ & $\begin{array}{l}-0.017 \\
(0.056)\end{array}$ & & $\begin{array}{l}-0.064 \\
(0.041)\end{array}$ & $\begin{array}{l}-0.029 \\
(0.048)\end{array}$ & & $\begin{array}{c}0.010 \\
(0.033)\end{array}$ & & $\begin{array}{l}-0.007 \\
(0.037)\end{array}$ \\
\hline \% Households w/ Plumbing (1960) & & $\begin{array}{l}-0.732 \\
(0.515)\end{array}$ & $\begin{array}{l}-0.495 \\
(0.568)\end{array}$ & & $\begin{array}{l}-0.054 \\
(0.425)\end{array}$ & $\begin{array}{c}0.051 \\
(0.482)\end{array}$ & & $\begin{array}{c}0.438 \\
(0.341)\end{array}$ & & $\begin{array}{l}-0.389 \\
(0.373)\end{array}$ \\
\hline \% Income < \$3,000 (1959) & & $\begin{array}{c}-1.334^{* *} \\
(0.557)\end{array}$ & $\begin{array}{l}-0.768 \\
(0.659)\end{array}$ & & $\begin{array}{l}-0.510 \\
(0.460)\end{array}$ & $\begin{array}{l}-0.163 \\
(0.562)\end{array}$ & & $\begin{array}{c}0.635^{*} \\
(0.373)\end{array}$ & & $\begin{array}{l}-0.524 \\
(0.442)\end{array}$ \\
\hline Ln (Total Population) (1960) & & $\begin{array}{c}0.120^{* *} \\
(0.045)\end{array}$ & $\begin{array}{c}0.124^{* *} \\
(0.050)\end{array}$ & & $\begin{array}{c}0.059 \\
(0.037)\end{array}$ & $\begin{array}{c}0.098^{* *} \\
(0.043)\end{array}$ & & $\begin{array}{l}-0.042 \\
(0.030)\end{array}$ & & $\begin{array}{c}0.079 * * \\
(0.034)\end{array}$ \\
\hline \% Population Urban (1960) & & $\begin{array}{l}-0.213 \\
(0.168)\end{array}$ & $\begin{array}{c}-0.352 * \\
(0.188)\end{array}$ & & $\begin{array}{l}-0.101 \\
(0.139)\end{array}$ & $\begin{array}{c}-0.280^{*} \\
(0.160)\end{array}$ & & $\begin{array}{c}0.073 \\
(0.111)\end{array}$ & & $\begin{array}{l}-0.214 \\
(0.127)\end{array}$ \\
\hline Ln (Per-pupil Real AV) (1961) & & $\begin{array}{c}0.080 \\
(0.063)\end{array}$ & $\begin{array}{c}0.100 \\
(0.072)\end{array}$ & & $\begin{array}{c}0.002 \\
(0.052)\end{array}$ & $\begin{array}{l}-0.026 \\
(0.061)\end{array}$ & & $\begin{array}{l}-0.062 \\
(0.041)\end{array}$ & & $\begin{array}{c}0.047 \\
(0.048)\end{array}$ \\
\hline Ln (Per-pupil Non-real AV) (1961) & & $\begin{array}{c}-0.109 * \\
(0.064)\end{array}$ & $\begin{array}{c}-0.128^{*} \\
(0.071)\end{array}$ & & $\begin{array}{l}-0.039 \\
(0.053)\end{array}$ & $\begin{array}{l}-0.002 \\
(0.061)\end{array}$ & & $\begin{array}{c}0.053 \\
(0.042)\end{array}$ & & $\begin{array}{l}-0.067 \\
(0.046)\end{array}$ \\
\hline Per-pupil Current Expenditure (1961/62 & & $\begin{array}{c}0.131 \\
(0.098)\end{array}$ & $\begin{array}{c}0.268^{* *} \\
(0.125)\end{array}$ & & $\begin{array}{l}-0.054 \\
(0.081)\end{array}$ & $\begin{array}{l}-0.022 \\
(0.105)\end{array}$ & & $\begin{array}{c}-0.126^{*} \\
(0.065)\end{array}$ & & $\begin{array}{c}0.103 \\
(0.081)\end{array}$ \\
\hline Lagged Change (1961-1964) & & & $\begin{array}{c}0.616 \\
(0.465)\end{array}$ & & & $\begin{array}{l}-0.136 \\
(0.314)\end{array}$ & & $\begin{array}{c}0.334 \\
(0.703)\end{array}$ & & $\begin{array}{c}0.318 \\
(0.350)\end{array}$ \\
\hline Change in Ln (Lagged Births) & & & $\begin{array}{c}0.527 \\
(0.380)\end{array}$ & & & $\begin{array}{c}0.013 \\
(0.424)\end{array}$ & & & & $\begin{array}{c}0.330 \\
(0.311)\end{array}$ \\
\hline Constant & $\begin{array}{c}0.366^{* * *} \\
(0.061)\end{array}$ & $\begin{array}{c}0.451 \\
(0.658)\end{array}$ & $\begin{array}{l}-0.512 \\
(0.846)\end{array}$ & $\begin{array}{c}0.231^{* * *} \\
(0.049)\end{array}$ & $\begin{array}{c}0.554 \\
(0.543)\end{array}$ & $\begin{array}{l}-0.313 \\
(0.720)\end{array}$ & $\begin{array}{c}-0.101^{* *} \\
(0.039)\end{array}$ & $\begin{array}{c}0.001 \\
(0.439)\end{array}$ & $\begin{array}{c}0.231 * * * \\
(0.043)\end{array}$ & $\begin{array}{l}-0.153 \\
(0.566)\end{array}$ \\
\hline Observations & 63 & 63 & 52 & 63 & 63 & 52 & 63 & 63 & 63 & 52 \\
\hline R-squared & 0.50 & 0.61 & 0.67 & 0.26 & 0.37 & 0.42 & 0.29 & 0.42 & 0.39 & 0.63 \\
\hline
\end{tabular}

Notes: Cameron Parish excluded. * significant at 10\%; ** significant at 5\%; *** significant at $1 \%$. ${ }^{*}$ Lagged births is calculated by adding the number of births for all cohorts who would be aged 6-18 in the fall of the school year born in the Parish, separately by race where appropriate. Birth data are only available for 52 Parishes. 
Table 3. Correlates of Change in Assessed Valuation (1965/66 to 1970/71)

\begin{tabular}{|c|c|c|c|c|c|c|c|c|c|}
\hline & \multicolumn{3}{|c|}{ Ln(Total Assessed Valuation) } & \multicolumn{2}{|c|}{ Ln(Real Estate AV) } & \multicolumn{2}{|c|}{ Ln(Non-Real Estate AV) } & \multicolumn{2}{|c|}{ Ln(Per-Pupil Total AV) } \\
\hline & (1) & (2) & (3) & (4) & (5) & (6) & (7) & (8) & (9) \\
\hline Black Share of Enrollment (1961/62) & $\begin{array}{l}-0.004 \\
(0.103)\end{array}$ & $\begin{array}{l}-0.175 \\
(0.127)\end{array}$ & $\begin{array}{l}-0.206 \\
(0.126)\end{array}$ & $\begin{array}{l}-0.111 \\
(0.070)\end{array}$ & $\begin{array}{l}-0.141 \\
(0.090)\end{array}$ & $\begin{array}{c}0.020 \\
(0.148)\end{array}$ & $\begin{array}{l}-0.229 \\
(0.187)\end{array}$ & $\begin{array}{c}0.606^{* * *} \\
(0.122)\end{array}$ & $\begin{array}{c}0.478^{* * *} \\
(0.158)\end{array}$ \\
\hline Per Capita Income (\$1000s) (1959) & & $\begin{array}{l}-0.046 \\
(0.036)\end{array}$ & $\begin{array}{c}-0.065^{*} \\
(0.034)\end{array}$ & & $\begin{array}{l}-0.026 \\
(0.026)\end{array}$ & & $\begin{array}{l}-0.044 \\
(0.053)\end{array}$ & & $\begin{array}{l}-0.006 \\
(0.045)\end{array}$ \\
\hline \% Households w/ Plumbing (1960) & & $\begin{array}{l}-0.488 \\
(0.369)\end{array}$ & $\begin{array}{l}-0.551 \\
(0.370)\end{array}$ & & $\begin{array}{l}-0.204 \\
(0.263)\end{array}$ & & $\begin{array}{l}-0.725 \\
(0.547)\end{array}$ & & $\begin{array}{l}-0.066 \\
(0.462)\end{array}$ \\
\hline$\%$ Income $<\$ 3,000(1959)$ & & $\begin{array}{c}-0.756^{*} \\
(0.400)\end{array}$ & $\begin{array}{c}-0.967 * * \\
(0.378)\end{array}$ & & $\begin{array}{c}-0.482^{*} \\
(0.285)\end{array}$ & & $\begin{array}{l}-0.878 \\
(0.591)\end{array}$ & & $\begin{array}{c}0.133 \\
(0.500)\end{array}$ \\
\hline Ln (Total Population) (1960) & & $\begin{array}{c}0.069 * * \\
(0.032)\end{array}$ & $\begin{array}{c}0.067 * * \\
(0.032)\end{array}$ & & $\begin{array}{c}0.027 \\
(0.023)\end{array}$ & & $\begin{array}{l}0.089 * \\
(0.048)\end{array}$ & & $\begin{array}{l}-0.007 \\
(0.040)\end{array}$ \\
\hline \% Population Urban (1960) & & $\begin{array}{l}-0.167 \\
(0.121)\end{array}$ & $\begin{array}{l}-0.157 \\
(0.119)\end{array}$ & & $\begin{array}{l}-0.004 \\
(0.086)\end{array}$ & & $\begin{array}{l}-0.264 \\
(0.178)\end{array}$ & & $\begin{array}{l}-0.020 \\
(0.151)\end{array}$ \\
\hline Ln (Per-pupil Real AV) (1961) & & $\begin{array}{c}-0.077^{*} \\
(0.045)\end{array}$ & & & $\begin{array}{c}0.004 \\
(0.032)\end{array}$ & & $\begin{array}{l}-0.100 \\
(0.066)\end{array}$ & & $\begin{array}{c}-0.115^{* *} \\
(0.056)\end{array}$ \\
\hline Ln (Per-pupil Non-real AV) (1961) & & $\begin{array}{c}0.050 \\
(0.046)\end{array}$ & & & $\begin{array}{l}-0.051 \\
(0.033)\end{array}$ & & $\begin{array}{c}0.078 \\
(0.068)\end{array}$ & & $\begin{array}{l}0.113 * \\
(0.057)\end{array}$ \\
\hline Per-pupil Current Expenditure (1961/62) & & $\begin{array}{l}-0.078 \\
(0.071)\end{array}$ & $\begin{array}{l}-0.062 \\
(0.070)\end{array}$ & & $\begin{array}{l}-0.009 \\
(0.050)\end{array}$ & & $\begin{array}{l}-0.122 \\
(0.104)\end{array}$ & & $\begin{array}{l}-0.124 \\
(0.088)\end{array}$ \\
\hline Constant & $\begin{array}{c}0.240^{* * *} \\
(0.045)\end{array}$ & $\begin{array}{c}0.769 \\
(0.472)\end{array}$ & $\begin{array}{c}0.953^{* *} \\
(0.442)\end{array}$ & $\begin{array}{c}0.232^{* * *} \\
(0.031)\end{array}$ & $\begin{array}{l}0.588^{*} \\
(0.336)\end{array}$ & $\begin{array}{c}0.254 * * * \\
(0.065)\end{array}$ & $\begin{array}{c}0.897 \\
(0.698)\end{array}$ & $\begin{array}{c}-0.199 * * * \\
(0.053)\end{array}$ & $\begin{array}{c}0.198 \\
(0.590)\end{array}$ \\
\hline Observations & 63 & 63 & 63 & 63 & 63 & 63 & 63 & 63 & 63 \\
\hline R-squared & 0.00 & 0.25 & 0.20 & 0.04 & 0.21 & 0.00 & 0.20 & 0.29 & 0.40 \\
\hline
\end{tabular}


Table 4. Correlates of Change in Per-Pupil Revenue by Source (1965/66 to 1970/71)

\begin{tabular}{|c|c|c|c|c|c|c|c|c|c|}
\hline & \multicolumn{3}{|c|}{ Total } & \multicolumn{3}{|c|}{ Non-Local } & \multicolumn{3}{|c|}{ Local } \\
\hline & (1) & (2) & (3) & (4) & (5) & (6) & (7) & (8) & (9) \\
\hline Black Share of Enrollment (1961/62) & $\begin{array}{c}1.453^{* * *} \\
(0.303)\end{array}$ & $\begin{array}{c}1.540^{* * *} \\
(0.368)\end{array}$ & $\begin{array}{c}1.527 * * * \\
(0.368)\end{array}$ & $\begin{array}{c}1.272^{* * * *} \\
(0.223)\end{array}$ & $\begin{array}{c}1.150^{* * *} \\
(0.267)\end{array}$ & $\begin{array}{c}1.151 * * * \\
(0.269)\end{array}$ & $\begin{array}{c}0.180 \\
(0.184)\end{array}$ & $\begin{array}{l}0.390^{*} \\
(0.225)\end{array}$ & $\begin{array}{l}0.374^{*} \\
(0.211)\end{array}$ \\
\hline Per Capita Income (\$1000s) (1959) & & $\begin{array}{c}0.052 \\
(0.104)\end{array}$ & $\begin{array}{c}0.041 \\
(0.104)\end{array}$ & & $\begin{array}{l}-0.016 \\
(0.075)\end{array}$ & $\begin{array}{l}-0.019 \\
(0.076)\end{array}$ & & $\begin{array}{l}0.068 \\
(0.064)\end{array}$ & $\begin{array}{c}0.043 \\
(0.060)\end{array}$ \\
\hline \% Households w/ Plumbing (1960) & & $\begin{array}{l}1.031 \\
(1.074)\end{array}$ & $\begin{array}{c}0.636 \\
(1.133)\end{array}$ & & $\begin{array}{c}1.069 \\
(0.778)\end{array}$ & $\begin{array}{c}1.178 \\
(0.822)\end{array}$ & & $\begin{array}{l}-0.038 \\
(0.656)\end{array}$ & $\begin{array}{l}-0.311 \\
(0.622)\end{array}$ \\
\hline$\%$ Income $<\$ 3,000(1959)$ & & $\begin{array}{l}1.959 * \\
(1.161)\end{array}$ & $\begin{array}{c}1.714 \\
(1.181)\end{array}$ & & $\begin{array}{c}1.326 \\
(0.842)\end{array}$ & $\begin{array}{c}1.374 \\
(0.855)\end{array}$ & & $\begin{array}{c}0.633 \\
(0.709)\end{array}$ & $\begin{array}{c}0.395 \\
(0.670)\end{array}$ \\
\hline Ln (Total Population) (1960) & & $\begin{array}{l}-0.034 \\
(0.094)\end{array}$ & $\begin{array}{l}-0.032 \\
(0.094)\end{array}$ & & $\begin{array}{l}-0.073 \\
(0.068)\end{array}$ & $\begin{array}{l}-0.077 \\
(0.069)\end{array}$ & & $\begin{array}{c}0.039 \\
(0.057)\end{array}$ & $\begin{array}{c}0.031 \\
(0.054)\end{array}$ \\
\hline \% Population Urban (1960) & & $\begin{array}{l}0.335 \\
(0.350)\end{array}$ & $\begin{array}{c}0.438 \\
(0.363)\end{array}$ & & $\begin{array}{c}0.178 \\
(0.254)\end{array}$ & $\begin{array}{c}0.166 \\
(0.257)\end{array}$ & & $\begin{array}{l}0.158 \\
(0.214)\end{array}$ & $\begin{array}{c}0.287 \\
(0.206)\end{array}$ \\
\hline Ln (Per-pupil Real AV) (1961) & & $\begin{array}{c}0.077 \\
(0.130)\end{array}$ & $\begin{array}{c}0.072 \\
(0.130)\end{array}$ & & $\begin{array}{l}-0.059 \\
(0.095)\end{array}$ & $\begin{array}{l}-0.066 \\
(0.097)\end{array}$ & & $\begin{array}{l}0.136^{*} \\
(0.080)\end{array}$ & $\begin{array}{c}0.102 \\
(0.076)\end{array}$ \\
\hline Ln (Per-pupil Non-real AV) (1961) & & $\begin{array}{c}-0.229 * \\
(0.133)\end{array}$ & $\begin{array}{l}-0.209 \\
(0.134)\end{array}$ & & $\begin{array}{l}-0.070 \\
(0.096)\end{array}$ & $\begin{array}{l}-0.065 \\
(0.098)\end{array}$ & & $\begin{array}{c}-0.158^{*} \\
(0.081)\end{array}$ & $\begin{array}{l}-0.107 \\
(0.078)\end{array}$ \\
\hline Per-pupil Current Expenditure (1961/62) & & $\begin{array}{c}-0.498^{* *} \\
(0.205)\end{array}$ & $\begin{array}{c}-0.555^{* *} \\
(0.211)\end{array}$ & & $\begin{array}{c}-0.438^{* * *} \\
(0.149)\end{array}$ & $\begin{array}{c}-0.419 * * * \\
(0.156)\end{array}$ & & $\begin{array}{l}-0.059 \\
(0.125)\end{array}$ & $\begin{array}{l}-0.086 \\
(0.118)\end{array}$ \\
\hline Lagged Change (1961-1964) & & & $\begin{array}{l}0.417 \\
(0.386)\end{array}$ & & & $\begin{array}{l}-0.194 \\
(0.440)\end{array}$ & & & $\begin{array}{c}0.700 * * * \\
(0.243)\end{array}$ \\
\hline Constant & $\begin{array}{c}0.452 * * * \\
(0.132)\end{array}$ & $\begin{array}{c}0.270 \\
(1.371)\end{array}$ & $\begin{array}{c}0.752 \\
(1.440)\end{array}$ & $\begin{array}{c}0.210^{* *} \\
(0.097)\end{array}$ & $\begin{array}{c}1.067 \\
(0.994)\end{array}$ & $\begin{array}{c}0.984 \\
(1.019)\end{array}$ & $\begin{array}{c}0.242 * * * \\
(0.080)\end{array}$ & $\begin{array}{l}-0.797 \\
(0.838)\end{array}$ & $\begin{array}{l}-0.289 \\
(0.805)\end{array}$ \\
\hline Observations & 63 & 63 & 63 & 63 & 63 & 63 & 63 & 63 & 63 \\
\hline R-squared & 0.27 & 0.47 & 0.48 & 0.35 & 0.54 & 0.54 & 0.02 & 0.27 & 0.37 \\
\hline
\end{tabular}


Table 5. Correlates of Change in Per-Pupil Non-Local Revenue by Source (1965/66 to 1970/71)

Nonlocal Sources

\begin{tabular}{|c|c|c|c|c|c|c|c|}
\hline \multicolumn{8}{|c|}{ Nonlocal Sources } \\
\hline \multicolumn{2}{|c|}{ Total } & \multicolumn{2}{|c|}{ Federal ESEA } & \multicolumn{2}{|c|}{ Minimum Foundation } & \multicolumn{2}{|c|}{ Other Non-Local } \\
\hline (1) & (2) & (3) & (4) & (5) & (6) & (7) & (8) \\
\hline $1.272 * * *$ & $1.150^{* * *}$ & $0.592 * * *$ & $0.536 * * *$ & $0.540 * * *$ & $0.522^{* * *}$ & $0.141 *$ & 0.092 \\
\hline & $\begin{array}{l}(0.267) \\
-0.016\end{array}$ & & $\begin{array}{c}(0.167) \\
0.012\end{array}$ & & $\begin{array}{l}(0.124) \\
-0.007\end{array}$ & & $\begin{array}{l}(0.104) \\
-0.022\end{array}$ \\
\hline & $(0.075)$ & & $(0.047)$ & & $(0.035)$ & & $(0.029)$ \\
\hline & 1.069 & & 0.673 & & 0.385 & & 0.011 \\
\hline & $(0.778)$ & & $(0.486)$ & & $(0.362)$ & & $(0.303)$ \\
\hline & 1.326 & & $0.898 *$ & & 0.299 & & 0.128 \\
\hline & $(0.842)$ & & $(0.526)$ & & $(0.392)$ & & $(0.327)$ \\
\hline & -0.073 & & -0.022 & & $-0.059 *$ & & 0.008 \\
\hline & $(0.068)$ & & $(0.043)$ & & $(0.032)$ & & $(0.027)$ \\
\hline & 0.178 & & -0.154 & & $0.212^{*}$ & & 0.120 \\
\hline & $(0.254)$ & & $(0.159)$ & & $(0.118)$ & & $(0.099)$ \\
\hline & -0.059 & & -0.021 & & -0.015 & & -0.023 \\
\hline & $(0.095)$ & & $(0.059)$ & & $(0.044)$ & & $(0.037)$ \\
\hline & -0.070 & & -0.027 & & -0.066 & & 0.023 \\
\hline & $(0.096)$ & & $(0.060)$ & & $(0.045)$ & & $(0.038)$ \\
\hline & $-0.438 * * *$ & & -0.108 & & $-0.289 * * *$ & & -0.041 \\
\hline & $(0.149)$ & & (0.093) & & $(0.069)$ & & $(0.058)$ \\
\hline $0.210^{* *}$ & 1.067 & -0.005 & -0.213 & $0.183^{* * *}$ & $1.207^{* *}$ & 0.032 & 0.073 \\
\hline$(0.097)$ & (0.994) & $(0.058)$ & $(0.621)$ & $(0.049)$ & $(0.462)$ & $(0.034)$ & $(0.387)$ \\
\hline 63 & 63 & 63 & 63 & 63 & 63 & 63 & 63 \\
\hline 0.35 & 0.54 & 0.24 & 0.42 & 0.28 & 0.56 & 0.05 & 0.16 \\
\hline
\end{tabular}

Notes: Cameron Parish excluded. Left-hand-side variables are in thousands of constant 2003 dollars.

$*$ significant at $10 \%$; $* *$ significant at $5 \%$; *** significant at $1 \%$ 
Table 6. Correlates of Change in Student-Teacher Ratios by Race (1965/66 to 1970/71)

\begin{tabular}{|c|c|c|c|c|c|c|}
\hline & \multicolumn{2}{|c|}{ Student-Teacher Ratio } & \multicolumn{2}{|c|}{ White S-T Ratio } & \multicolumn{2}{|c|}{ Black S-T Ratio } \\
\hline & $(1)$ & $(2)$ & (3) & (4) & $(5)$ & $(6)$ \\
\hline Black Share of Enrollment (1961/62) & $\begin{array}{c}-5.001 * * * \\
(1.113)\end{array}$ & $\begin{array}{c}-5.089 \text { *** } \\
(1.309)\end{array}$ & $\begin{array}{l}1.888^{*} \\
(1.079)\end{array}$ & $\begin{array}{c}1.046 \\
(1.362)\end{array}$ & $\begin{array}{c}-5.823^{* *} \\
(2.200)\end{array}$ & $\begin{array}{c}-5.382^{* *} \\
(2.667)\end{array}$ \\
\hline Per Capita Income (\$1000s) (1959) & & $\begin{array}{l}-0.221 \\
(0.370)\end{array}$ & & $\begin{array}{c}0.012 \\
(0.385)\end{array}$ & & $\begin{array}{l}-0.391 \\
(0.754)\end{array}$ \\
\hline \% Households w/ Plumbing (1960) & & $\begin{array}{l}-5.837 \\
(3.819)\end{array}$ & & $\begin{array}{l}-3.923 \\
(3.972)\end{array}$ & & $\begin{array}{c}-10.826 \\
(7.780)\end{array}$ \\
\hline$\%$ Income $<\$ 3,000(1959)$ & & $\begin{array}{c}-11.113^{* * *} \\
(4.130)\end{array}$ & & $\begin{array}{l}-4.725 \\
(4.295)\end{array}$ & & $\begin{array}{c}-20.625^{* *} \\
(8.413)\end{array}$ \\
\hline Ln (Total Population) (1960) & & $\begin{array}{c}0.389 \\
(0.334)\end{array}$ & & $\begin{array}{c}0.481 \\
(0.348)\end{array}$ & & $\begin{array}{c}0.265 \\
(0.681)\end{array}$ \\
\hline \% Population Urban (1960) & & $\begin{array}{l}-1.837 \\
(1.246)\end{array}$ & & $\begin{array}{c}-3.418^{* *} \\
(1.296)\end{array}$ & & $\begin{array}{l}-0.334 \\
(2.539)\end{array}$ \\
\hline Ln (Per-pupil Real AV) (1961) & & $\begin{array}{c}0.751 \\
(0.464)\end{array}$ & & $\begin{array}{c}0.083 \\
(0.482)\end{array}$ & & $\begin{array}{c}1.973^{* *} \\
(0.945)\end{array}$ \\
\hline Ln (Per-pupil Non-real AV) (1961) & & $\begin{array}{l}-0.199 \\
(0.473)\end{array}$ & & $\begin{array}{c}0.503 \\
(0.492)\end{array}$ & & $\begin{array}{l}-1.485 \\
(0.964)\end{array}$ \\
\hline Per-pupil Current Expenditure (1961/62) & & $\begin{array}{c}1.979 * * * \\
(0.729)\end{array}$ & & $\begin{array}{c}1.005 \\
(0.758)\end{array}$ & & $\begin{array}{l}2.937^{*} \\
(1.485)\end{array}$ \\
\hline Constant & $\begin{array}{c}0.957 * \\
(0.486)\end{array}$ & $\begin{array}{c}1.865 \\
(4.877)\end{array}$ & $\begin{array}{l}-0.260 \\
(0.471)\end{array}$ & $\begin{array}{l}-2.886 \\
(5.072)\end{array}$ & $\begin{array}{l}-1.017 \\
(0.960)\end{array}$ & $\begin{array}{c}6.717 \\
(9.936)\end{array}$ \\
\hline Observations & 63 & 63 & 63 & 63 & 63 & 63 \\
\hline R-squared & 0.25 & 0.48 & 0.05 & 0.25 & 0.10 & 0.34 \\
\hline
\end{tabular}

Notes: Cameron Parish excluded. For 1965, the district-level student-teacher ratio for blacks is the total number of black students divided by the number of black teachers in the district; the white ratio is calculated similarly. In 1970, students and faculty were desegregated; blacks and whites are both assumed to have the average student-teacher ratio.

* significant at $10 \%$; ** significant at $5 \%$; *** significant at $1 \%$ 
Table 7. Decomposition of Differential Change in State PSF Revenue

\begin{tabular}{|c|c|c|c|c|c|}
\hline & 1965 & 1970 & 1973 & Change 1965-70 & Change 1965-73 \\
\hline Coefficient on $\%$ Black & 322 & 862 & 813 & 540 & 491 \\
\hline \multicolumn{6}{|l|}{ Percent Attributable to: } \\
\hline Program Costs & $90 \%$ & $104 \%$ & $96 \%$ & $112 \%$ & $100 \%$ \\
\hline Salaries & $46 \%$ & $52 \%$ & $60 \%$ & $55 \%$ & $70 \%$ \\
\hline Transportation & $41 \%$ & $32 \%$ & $26 \%$ & $26 \%$ & $17 \%$ \\
\hline Per-ADM Instruction Costs & $3 \%$ & $6 \%$ & $2 \%$ & $8 \%$ & $1 \%$ \\
\hline Declining Enrollment & $0 \%$ & $14 \%$ & $0 \%$ & $23 \%$ & $0 \%$ \\
\hline Salary Adjustment & $0 \%$ & $0 \%$ & $7 \%$ & $0 \%$ & $12 \%$ \\
\hline Required Support (Negative) & $30 \%$ & $-6 \%$ & $0 \%$ & $-27 \%$ & $-20 \%$ \\
\hline 5 Mill Constitutional Tax & $9 \%$ & $-1 \%$ & $-2 \%$ & $-7 \%$ & $-9 \%$ \\
\hline Severance Tax & $-2 \%$ & $-8 \%$ & $-7 \%$ & $-12 \%$ & $-11 \%$ \\
\hline Rent or Lease of Lands & $23 \%$ & $3 \%$ & $9 \%$ & $-8 \%$ & $0 \%$ \\
\hline Other Adjustments & $-18 \%$ & $1 \%$ & $4 \%$ & $13 \%$ & $18 \%$ \\
\hline \multicolumn{6}{|c|}{$\begin{array}{l}\text { Notes: Cameron Parish excluded. All per-pupil revenue figures are reported are in constant } 2003 \text { dollars. } \\
\text { Program costs include allotment for salaries of teachers, visiting teachers, supervisors, and transportation, adjustments for } \\
\text { districts with declining enrollments (1970), and adjustments for teacher salaries (1973). Required support includes the } \\
\text { proceeds of the } 5 \text { mill Constitutional and severance tax and half of the funds received from rent or lease of school lands. } \\
\text { Information on the breakdown of program costs and required support for the following school year was reported in the } \\
\text { Annual Report, while actual payments from the Public School Fund was reported in the Annual Report of the same year; } \\
\text { other adjustments is the difference between payments from the PSF and program costs less required support (these are } \\
\text { adjustments to PSF allocation made after the previous year's report was printed). }\end{array}$} \\
\hline
\end{tabular}

